\title{
Simulation of Steel Corrosion in Concrete Based on the Model of Macro-Cell Corrosion Circuit
}

\author{
Tsuyoshi Maruya ${ }^{1}$, Hitoshi Takeda ${ }^{1}$, Kenichi Horiguchi ${ }^{1}$, Satoru Koyama ${ }^{2}$ and Kai-Lin Hsu ${ }^{3}$
}

Received 3 November 2006, accepted 12 June 2007

\begin{abstract}
A comprehensive numerical simulation system is proposed for solving the problem of steel corrosion in concrete related to deterioration of reinforced concrete structures in an environment contaminated by chloride ions. The distribution of the corrosion amount and the corrosion rate along the reinforced bar were calculated based on macro-cell circuit models consisting of micro-cell circuits. The models were quantified according to the results of exposure experiments under two environments, one under cyclic wetting and drying in a laboratory and the other in a splash zone located offshore. The comparisons on time-dependent half-cell potential, corrosion location and corrosion amount indicate qualitative coincidence between the experimental and numerical simulation results. In addition, based on the proposed system, numerical simulation of the macro-cell corrosion circuit between patched area and not-yet-patched area is reasonably achieved.
\end{abstract}

\section{Introduction}

Corrosion of steel in concrete structures can be regarded as an oxidization process followed by the breakdown of the passive film of the steel due to the ingress of chloride ions or carbon oxide. Corrosion cracks are known not to directly happen at the surface of a concrete structure in the initial stage, but to only appear at the surface of a structure after a corrosive product reaches its threshold amount. Further, after the appearance of a corrosion crack at the surface, the corrosion rate significantly increases owing to the greater ingress flux of chloride ions or carbon oxide through the crack. Moreover, the safety of the structure will be threatened due to the propagation of the accelerated corrosion process. It is generally accepted to break down the aforementioned corrosion process into 4 stages, namely incubation, propagation, acceleration, and deterioration (Japan Soc. Civ. Eng. 2001).

This paper explains mainly how to compute the corrosion rate of steel in concrete. As the authors have already provided the outline of the computational flow for corrosion processes before and after the initiation of corrosion cracks (Hsu et al. 2000), the detailed kinetics for the formation of the macro-cell circuit in the presence of chloride ions and the corresponding corrosion rate are simulated with a model called multi-circuit model proposed in this paper, and this is followed by a comparative discussion of the exposure test results. However, consideration for simulating corrosion crack and accelerated

\footnotetext{
${ }^{1}$ Technology Research Center, Taisei Corporation, Japan. E-mail: tsuyoshi.maruya@sakura.taisei.co.jp

${ }^{2}$ Shinozuka Research Institute, Japan.

${ }^{3}$ Department of Construction Engineering, National Kaohsiung First University of Science and Technology, R.O.C.
}

corrosion rate due to corrosion crack is excluded in this paper owing to the different occurrence mechanism involved. The computational flow of the proposed numerical system is first explained by integrating simulation of the incubation and propagation period. Then, the details of the multi-circuit model for simulating the formation of half-cell potential and corrosion current density are further clarified. Finally, verification for comparing numerical and experimental results is implemented to verify whether this system for modeling the corrosion of steel in concrete structures under chloride attack is adequate. Besides, some discussions on the parameters considered in this numerical system are included to clarify their influences in this numerical system.

The macro-cell circuit is considered to be a corrosion circuit that occurs between the anode and cathode at a certain distance from each other, which has also been discussed in the case of steel in soil (Jones 1996). Conversely, a micro-cell circuit is considered to be a circuit with an anode and cathode at very close distance that can be even treated as a negligible distance. Although a massive amount of research on steel corrosion in concrete has already been done throughout the world (Japan Soc. Civ. Eng. 2000), there has been comparatively little research on the formation of macro-cell circuits and the macro-cell corrosion rate (Otsuki et al. 1999, Nagataki et al. 1997, Kawahigashi et al. 2003, Raupach 1996). This may be due to the fact that the corrosion of plain steel tends to be regarded as a micro-cell circuit and to be moderately easily experimented for model validation. However, it is also known that once there is heterogeneity during the steel corrosion process in concrete, there may be a drastic increase in the corrosion rate at anodic zones, significant increase of the corrosion rate at crack zones, considerable corrosion at not-yet-repaired areas close to the repaired sections, etc. As a result, clarification of macro-cell corrosion requires an understanding of 
the corrosion process of steel in concrete and is very important for accurate prediction of the corrosion process.

\section{Framework of simulation method for steel corrosion in concrete}

\subsection{Flow of numerical simulation system for calculating corrosion rate and corrosion amount}

The corrosion rate of steel in concrete mainly increases due to the formation of macro-cell circuits, unlike the corrosion process of steel, which causes under-estimation of the corrosion rate just by the intersect of the anodic polarization and cathodic polarization curves (Elsener 2003). As a result, it is essential to treat the corrosion process of steel in concrete as a macro-cell circuit both theoretically and practically. The computational flow of the proposed numerical system is illustrated in Fig. 1. First, the concentration of chloride ions (Maruya et al. 1998) and oxygen at the rebar (Hsu et al. 1998) are set based on mass transport models in concrete. With these values, the half-cell potential $\left(\mathrm{E}_{\text {micro }}\right)$ by micro-cell corrosion model can be calculated. The term "micro-cell corrosion model" here means the model to calculate the half-cell potential of the micro-cell circuit $\left(\mathrm{E}_{\text {micro }}\right)$ and the corrosion current density $\left(\mathrm{I}_{\text {micro }}\right)$ at the intersect point of the anodic polarization curve and the cathodic polarization curve within Evan's diagram. As known, the anodic polarization curve is the function of the ratio of chloride ion concentration and hydroxyl ion concentration $\left(\left[\mathrm{Cl}^{-}\right] /\left[\mathrm{OH}^{-}\right]\right)$at the position of the rebar, while the cathodic polarization curve is the function of

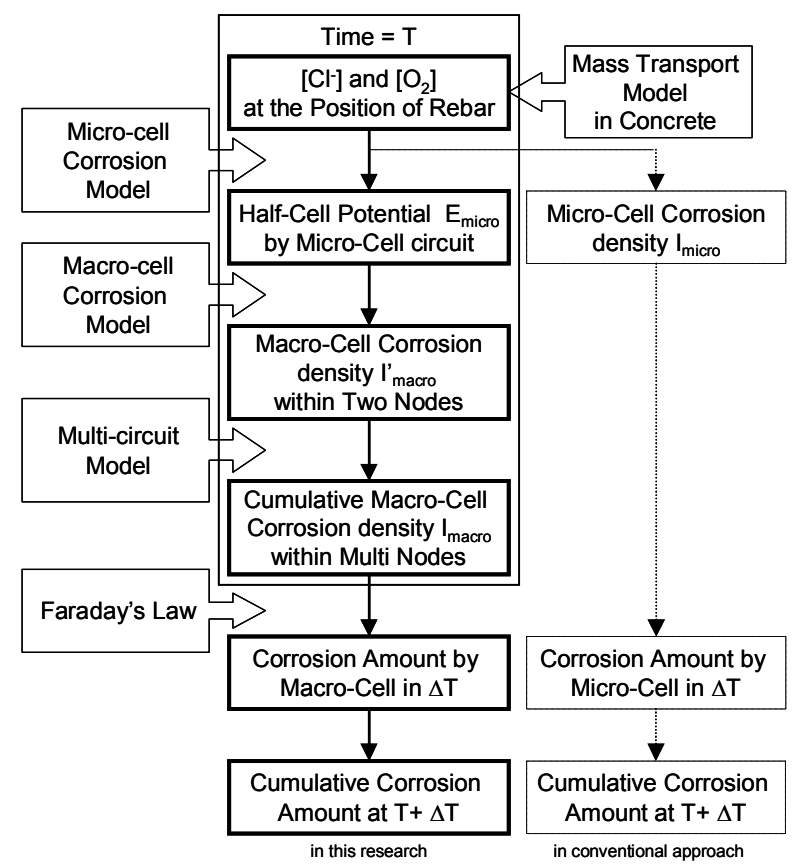

Fig. 1 Computational flow for simulation of incubation and propagation period. concentration of oxygen ions at the rebar. Although the current density can be calculated in the micro-cell corrosion model, there is no direct connection between such kind of current density and the corrosion rate of the rebar when a macro-cell circuit is formed Then, according to the macro-cell corrosion model, the half-cell potential $\left(\mathrm{E}^{\prime}\right.$ macro $)$ and current density of the macro-cell circuit ( $\mathrm{I}_{\text {macro }}$ ) can be calculated by the calculated half-cell potential of the micro-cell circuit $\left(\mathrm{E}_{\text {micro }}\right)$. The term "macro-cell corrosion model" here means the model for calculating the half-cell potential and the current density within the newly formatted circuit between two elements along the rebar(s), calculating ohmic drop. Next, as the half-cell potential ( $\mathrm{E}_{\text {'macro }}$ ) and current density ( $\mathrm{I}_{\text {macro }}$ ) in the circuit existing between any two elements can be developed by the macro-cell corrosion model, the multi-circuit model should be applied to all the possible circuits distributed between the elements along the rebar(s) for calculating the half-cell potential ( $\left.E_{\text {macro }}\right)$ and current density $\left(\mathrm{I}_{\text {macro }}\right)$ of each element. With the calculated current density, the amount of the corrosive product can be calculated by Faraday's law with the help of three sub-models, the micro-cell corrosion model, macro-cell corrosion model, and multi-circuit model.

\subsection{Proposal for micro-cell corrosion model}

As shown in Fig. 2, so-called micro-cell corrosion indicates the rebar corrosion phenomenon in concrete, wherein the cathodic current from the concrete to the rebar be equal to the anodic current from the rebar to the concrete at each element along the rebar (Hsu et al. 2000). Thus, for each element along the rebar, an anode and a cathode exist simultaneously. The mechanism for micro-cell corrosion can be realized from an Evans diagram, as shown in Fig. 3. A, $A_{1}, A_{2}$ and $A_{3}$ are anodic polarization curves at their respective concentration of chloride ions. Curve A depicts the case when there is no $\mathrm{Cl}^{-}$, and curves $A_{1}, A_{2}$ and $A_{3}$ correspond to the sequence of chloride concentration increase. On the other hand, curves $\mathrm{B}$ and $\mathrm{C}$ are cathodic polarization curves. $\mathrm{B}$ is the curve when there is a sufficient supply of oxygen, and $\mathrm{C}$ is the curve in the case of an insufficient supply of oxygen.

Regarding the axial notations in Fig. 3, $\mathrm{i}_{\mathrm{co}}, \mathrm{i}_{\text {pass }}, \mathrm{i}_{\text {micro }}$ and $i_{\text {lim }}$ denote the exchange current density on cathodic reaction, the current density at the formation of passive film, the current density of the micro-cell circuit at the intersect of anodic polarization $\mathrm{A}_{3}$ and cathodic polarization $\mathrm{B}$, and the limit current density controlled by the supply of oxygen, respectively, while $\mathrm{E}_{\mathrm{co}}, \mathrm{E}_{\text {trans }}, \mathrm{E}_{\text {pitx }}$ and $\mathrm{E}_{\text {micro }}$ mean the equilibrium potential on cathodic reaction, the pitting potential (i.e. transpassive potential) in the presence of alkalinity and no chloride ions, the corresponding potentials at the gradual drop with the increase of $\mathrm{Cl}^{-}(\mathrm{x}$ : noted in the sequence of 1,2 and 3), and the half-cell potential of the micro-cell circuit at the intersect of anodic polarization $\mathrm{A}_{3}$ and cathodic polarization B, respectively. 
The micro-cell corrosion is, as shown in Fig. 2, characterized as the half-cell potential when the anodic current and cathodic current for a given element is equal, which is the same as the intersect of the anodic polarization curve and cathodic polarization curve in Fig. 3. In Fig. 3, it is also observed that the passive current density $\left(i_{\text {pass }}\right)$ is the current density at the intersection of the anodic polarization curve (i.e., $\mathrm{A}, \mathrm{A}_{1}$ and $\mathrm{A}_{2}$, with the chloride amount under the chloride threshold value) and cathodic polarization curve B (with sufficient supply of oxygen). However, when the chloride amount at the rebar exceeds the chloride threshold value (i.e. $A_{3}$ ), the current density at the intersection of $A_{3}$ and $B$ is $i_{\text {micro }}$. Supported by the fact that $i_{\text {pass }}<<i_{\text {micro }}$ in Fig. 3, the fact that the corrosion rate after the destruction of the passive film becomes very high while the corrosion rate while a sound passive film exists is significantly lower can be conceptually accepted.

\subsection{Proposal for macro-cell corrosion model}

In the previous section, the algorithm to calculate $E_{\text {micro }}$ of the rebar under chloride corrosion is illustrated under
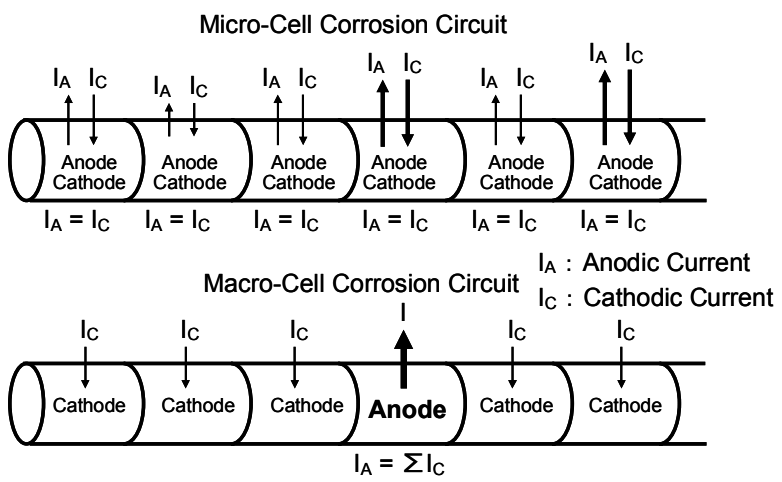

Fig. 2 Corrosion circuits for micro-cell and macro-cell models.

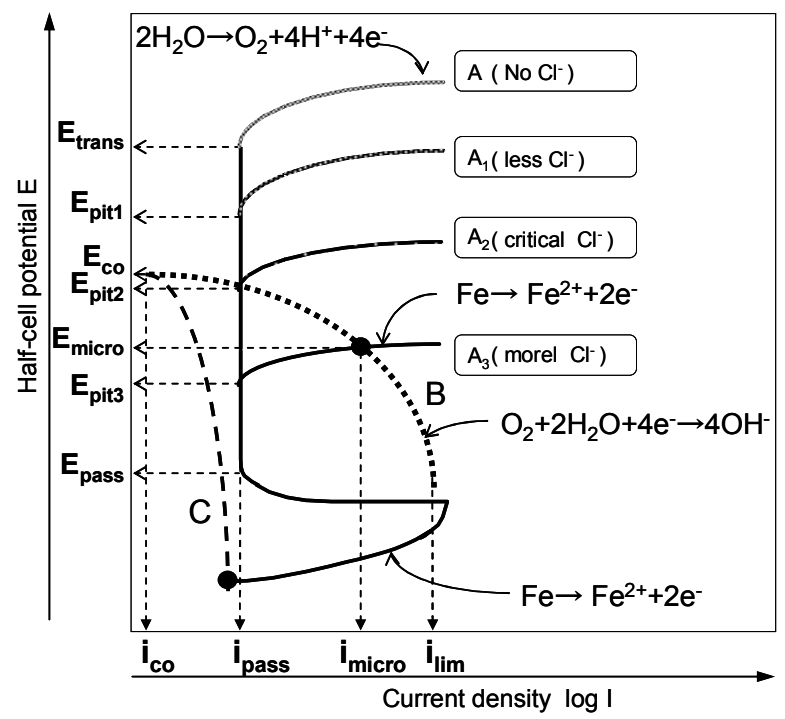

Fig. 3 Micro-cell corrosion model with alkalinity. the assumption that there is no interaction between separate electrodes. However, once pitting corrosion is initiated, there should be an interaction between separate electrodes due to the existence of polarization. As a result, a model for macro-cell corrosion is established by assuming the formation of a macro-cell as the interaction between separate electrodes. According to the assumption used in the previous section, after the formation of micro-cell potential, the state of separate electrodes should be regarded as stable. However, once the interaction between separate electrodes is taken into account, the activation polarization is indispensable for generating the essential activation energy required for the corrosion reactions. Thus, as shown in Fig. 2, macro-cell corrosion is related to the formation of a macro-cell circuit due to the separation between the anode and the cathode along the rebar. In this paper, the so-called macro-cell corrosion model means further polarization effect due to the difference in micro-cell potential; that is, as shown in Fig. 4, the symbols $(\bullet)$, which represent the electrodes formed due to micro-cell corrosion, consist of a new circuit between the electrodes, denoted by $\circ$. Regarding the axial notations in Fig. 4, $i_{m i, c}, E_{m i, c}, i_{m i, a}, E_{m i, a}, i_{m a, c}, E_{m a, c}$, $\mathrm{i}_{\mathrm{ma}, \mathrm{a}}$ and $\mathrm{E}_{\mathrm{ma}, \mathrm{a}}$ denote the micro-cell current density on cathodic reaction, the micro-cell potential on cathodic reaction, the micro-cell current density on anodic reaction, the micro-cell potential on anodic reaction, the formatted macro-cell current density on cathodic reaction, the formatted macro-cell potential on cathodic reaction, the formatted macro-cell current density on anodic reaction, and the formatted macro-cell potential on anodic reaction, respectively. The anode of the newly developed circuit (i.e. macro-cell circuit) is polarized from the electrode with lower potential while the cathode is polarized from the electrode with higher potential. Further, as can also be seen in Fig. 4, the newly developed polarization effect can be attributed to the potential

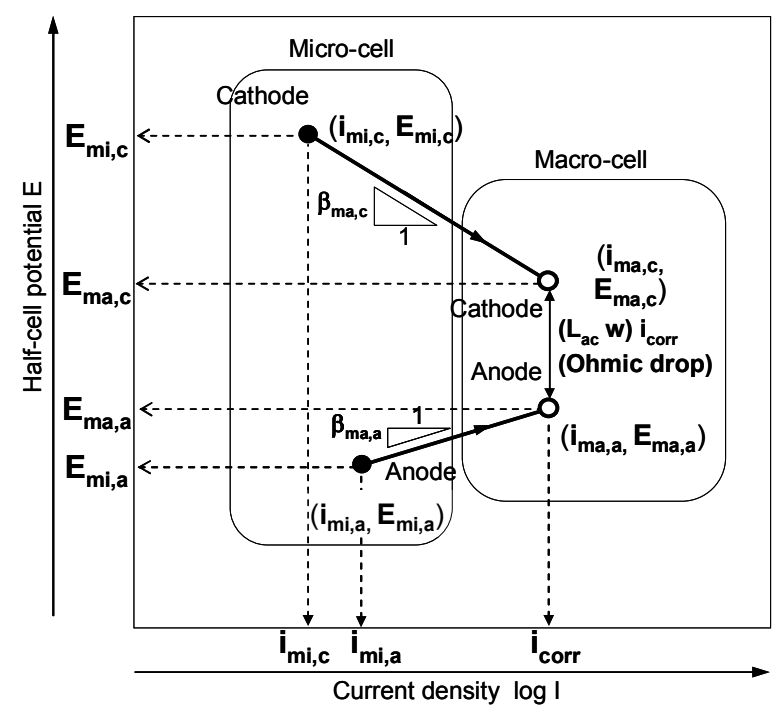

Fig. 4 Macro-cell corrosion model. 
difference from the concrete resistivity and the potential difference from polarization resistance, and the newly developed polarization effect will cause the current density at anode $\left(i_{\text {ma,a }}\right)$ equal to the current density at cathode $\left(i_{\text {ma,c }}\right)$, which is regarded as the macro-cell current density $i_{\text {corr }}$. Therefore, based on the above, for any two electrodes, the macro-cell current density ( $i_{\text {corr }}$, unit: $\mathrm{A} / \mathrm{cm}^{2}$ ), which is dominated by the concrete resistivity or polarization resistance, can be calculated by Eq. (1):

$$
E_{m a, c}-E_{m a, a}=\left(L_{a c} \cdot w\right) \cdot i_{c o r r}
$$

where $\mathrm{E}_{\mathrm{ma}, \mathrm{c}}, \mathrm{E}_{\mathrm{ma}, \mathrm{a}}=$ half-cell potential $(\mathrm{V}), \mathrm{L}_{\mathrm{ac}}=$ distance between anode and cathode $(\mathrm{cm})$, and $\mathrm{w}=$ concrete resistivity formed within the macro-cell circuit $(\Omega \mathrm{cm})$. Moreover, using the value calculated by the micro-cell model revealed in Eq. (1) and the Tafel slope of the polarization curve in Fig. 4, we obtain Eq. (2):

$$
\begin{aligned}
& E_{m a, c}-E_{m a, a}=\left(E_{m i, c}+\beta_{m a, c} \log \left(i_{c o r r} / i_{m i, c}\right)\right) \\
& -\left(E_{m i, a}+\beta_{m a, a} \log \left(i_{c o r r} / i_{m i, a}\right)\right)
\end{aligned}
$$

where $\beta_{\mathrm{ma}, \mathrm{c}}=$ Tafel slope of the cathodic polarization curve formed in the macro-cell circuit, and $\beta_{\mathrm{ma}, \mathrm{a}}=$ Tafel slope of the anodic polarization curve formed in the macro-cell circuit. It is worthy of note that the potential variations from the micro-cell circuit to macro-cell circuit, as shown in Fig. 4, are related to not only the polarization effect but also the concrete resistivity.

\subsection{Proposal for multi-circuit model}

As already explained, the model illustrated in Fig. 4 is valid for any two electrodes, as indicated in Fig. 2. However, as shown in Fig. 5, there are usually a number of electrodes distributed along any rebar; that is to say, there is more than one couple element $\mathrm{j}$ for target element $\mathbf{i}$ if target element $\mathbf{i}$ is considered. Thus, by applying the macro-cell corrosion model for all the existing element couples, the half-cell potential and current density for all the element couples can be calculated. For example, as shown in Fig. 6, the element with the lowest half-cell potential is taken as the target element while the half-cell potential and current density of the other elements as couple elements are obtained according to the micro-cell corrosion model (i.e. data set A, marked as $\circ$ ). Then, by applying the macro-cell corrosion model, the target element for all the couple elements is set to be anodes due to its lower potential, and is represented by $\Upsilon$ after further polarization, as shown in Fig. 6. Next, the macro-cell potential of the target element is determined by taking the average of all these calculated potentials within all the element couples, while the macro-cell current density of the target element is obtained by the accumulation of these calculated current densities within all the element couples. Furthermore, as also shown in Fig. 6, the current density calculated by macro-cell corrosion model may be smaller than the one calculated by the micro-cell corrosion model (i.e. data set B, marked as $\square)$. The corresponding value for target element $\mathbf{i}$, data set A and data set B in Fig. 4 is $\left(i_{m i, a}, E_{m i, a}\right),\left(i_{m i, c}, E_{m i, c}\right)$, and $\left(\mathrm{i}_{\mathrm{ma}, \mathrm{a}}, \mathrm{E}_{\mathrm{ma}, \mathrm{a}}\right)$, respectively. However, because this phenomenon cannot be the reason for the known polarization process, these current densities are not counted in the accumulation of the current densities. In addition, it is conceptually essential to emphasize that the measured half-cell potential be equal to the potential calculated by the multi-circuit model, not the potential calculated by the macro-cell corrosion model. Thus, in order to calculate the corrosion current density by the measured half-cell potential, it is unreasonable to directly utilize the ohmic rule with the difference of half-cell potential shown in Fig. 5 and the specific resistance of concrete (Koyama et al. 1996). In other words, the corrosion current density calculated by the measured half-cell potential between two elements is different from the current density illustrated in Fig. 4, while the half-cell potential of each element is also different from the half-cell potential shown in Fig. 4. However, if there is no formation of macro-cell circuit, it is still possible to apply the measured half-cell potential for the calculation of the corrosion current density of the multi-circuit model.

\subsection{Conversion from half-cell potential to cor- rosion current density}

In order to convert the measured half-cell potential into the corrosive product amount of the rebar, it is necessary to calculate the current density from the half-cell potential. By assuming the existence of macro-cell circuits formed between the electrically connected rebars, according to Eq. (3), the current density at target element $i$ can be calculated (Takewaka and Kobayashi 1988, Japan Conc. Inst. 1996). First, the current density within the macro-cell circuit between target element $\mathbf{i}$ and couple element $\mathbf{j}$ can be obtained based on the potential difference of the two elements, specific resistivity and distance between the two elements. Subsequently, for all couple elements $\mathbf{j}$, there should exist more than one macro-cell circuit. After calculating all the current densities for the possible circuits, the current density flowing into target element $\mathbf{i}$ is considered to be the accumulated current densities flowing from all the couple elements $\mathbf{j}$.

$$
I_{i}=\frac{1}{B \Delta L_{i}} \sum_{j=1}^{n} \frac{\delta E_{i, j}}{w \delta L_{i, j}} B \Delta L_{j}
$$

where $\mathrm{I}_{\mathrm{i}}=$ current density for element $\mathbf{i}\left(\mathrm{A} / \mathrm{cm}^{2}\right), \delta \mathrm{E}_{\mathrm{i}, \mathrm{j}}=$ potential difference between element $\mathbf{i}$ and $\mathbf{j}(\mathrm{V}), \delta \mathrm{L}_{\mathrm{i}, \mathrm{j}}=$ distance between element $\mathbf{i}$ and $\mathbf{j}(\mathrm{cm}), \mathrm{w}=$ specific resistivity of concrete $(\Omega \mathrm{cm}), \mathrm{B}=$ width of element $(\mathrm{cm})$, $\Delta \mathrm{L}_{\mathrm{i}}=$ length of element $\mathbf{i}(\mathrm{cm})$, and $\Delta \mathrm{L}_{\mathrm{j}}=$ length of element $\mathbf{j}(\mathrm{cm})$. 


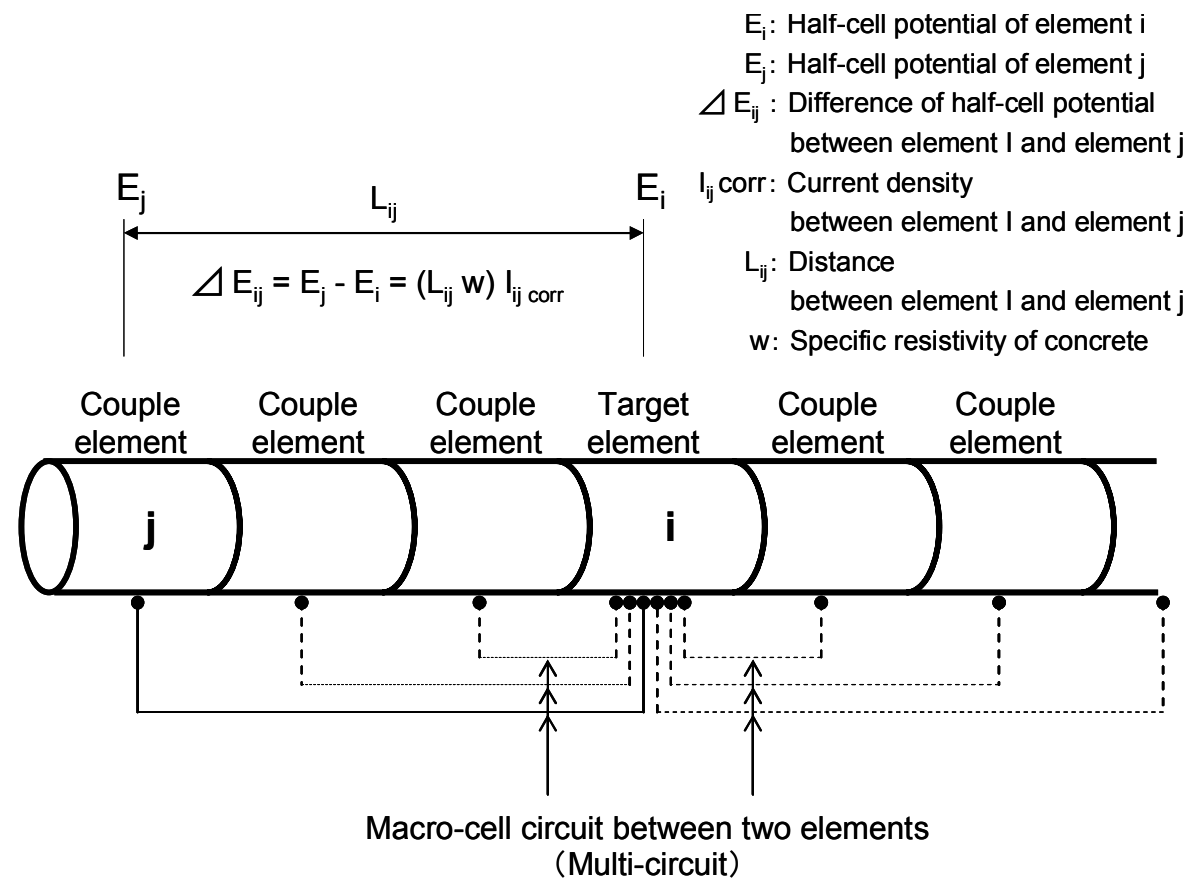

Fig. 5 Multi-circuits of macro-cell corrosion.

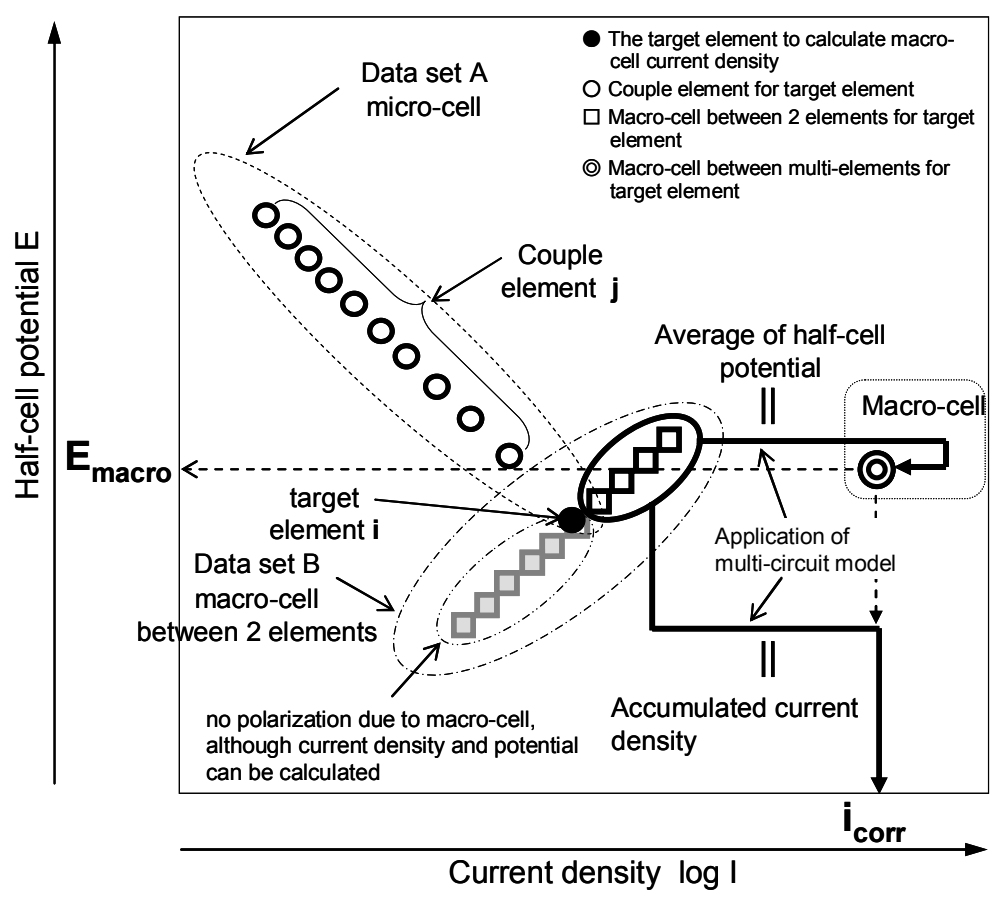

Fig. 6 Variations for half-cell potential and current density between micro-cell and macro-cell model.

\subsection{Conversion from corrosion current density to corrosive product amount}

The corrosive product amount $\mathbf{m}$ for target element $\mathbf{i}$ can be calculated with Eq. (4) (i.e. Faraday's rule) .

$$
m=\frac{I_{c o r r} \cdot t \cdot a}{n \cdot F}
$$

where $\mathrm{m}=$ corrosive product amount $\left(\mathrm{g} / \mathrm{cm}^{2}\right), \mathrm{I}_{\text {corr }}=$ corrosion current density $\left(\mathrm{A} / \mathrm{cm}^{2}\right), \mathrm{t}=$ time (second), $\mathrm{a}=$ atomic weight of $\mathrm{Fe}(=55.845 \mathrm{~g}), \mathrm{n}=$ valence of dissolved Fe ion (mol eq), F = Faraday's constant $(=96500$ $\mathrm{C} / \mathrm{mol} \mathrm{eq}$ ). 


\section{Experiments for validation of proposed models and formulation}

\subsection{Layout of the specimen, position of rebar and concrete mixture proportions}

The specimens (1200 mm long, $100 \mathrm{~mm}$ deep and 100 $\mathrm{mm}$ high with concrete cover thickness of $20 \mathrm{~mm}$ and rebar diameter of $13 \mathrm{~mm}$ (SD295A)) were exposed at indoor and outdoor sites. The layout of the specimens is illustrated in Fig. 7. To limit the movement of chloride only in the vertical direction, all the side surfaces of each specimen were coated by epoxy resin. In addition, the areas within $200 \mathrm{~mm}$ from the margin part of the exposure sides were also coated with acrylic resin for avoiding corrosion of the rebar ends. Since the placement of fresh concrete was along the axial direction of the specimen, the quality of the two-exposure surface can be kept constant, as shown in Fig. 7.

The mixture proportions of the concrete are shown in Table 1. The concrete is AE concrete with a water/cement ratio of 0.6 , maximum aggregate size of 20 $\mathrm{mm}$, and slump of $10 \mathrm{~cm}$. The curing period was over 28 days in $20^{\circ} \mathrm{C}$ water. The acrylic resin coating was finished during the curing period.

\subsection{Exposure conditions of the experiments}

Outdoor experiments were carried out to simulate the exposure conditions near the splash zone shown in Fig. 8. The specimens for the indoor experiments were exposed under cyclic wet-dry exposure (3-day immersion in $20^{\circ} \mathrm{C}$ salt water with $3 \% \mathrm{NaCl}$ and 4-day drying at $20^{\circ} \mathrm{C}$, $65 \%$ RH). As shown in Fig. 7, the two-opposite exposure surfaces of the specimen were kept uncoated at the vertical direction and the surface with cover thickness of 20 $\mathrm{mm}$ was kept facing downward.

\subsection{Items and method of Measurement}

To ascertain the deformation of the exposure specimens, visual inspection of corrosion cracks (location and scale) and measurement of half-cell potentials were periodically carried out. Also, when the half-cell potential fell under $-700 \mathrm{mv}$ (vs. CSE) as corrosion progressed, the specimens were split to investigate the corrosive product

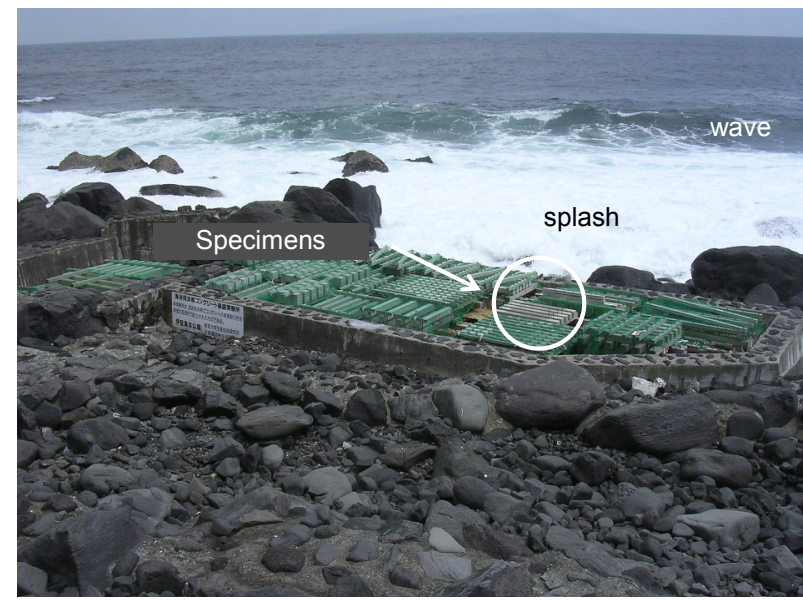

Fig. 8 Exposure environment in splash zone.

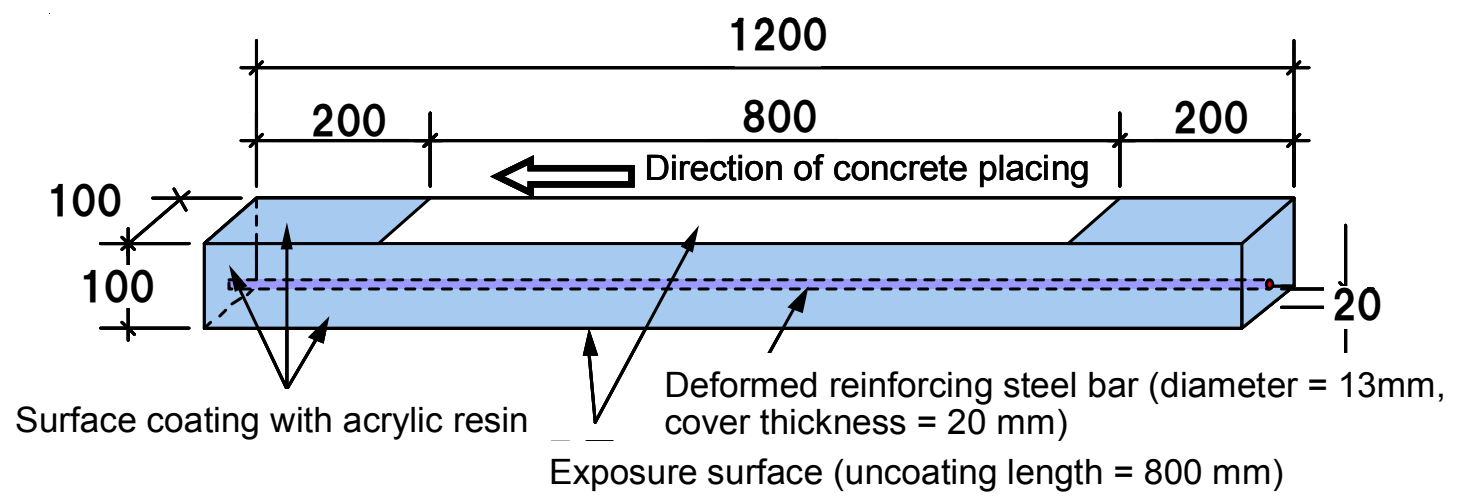

unit : $\mathrm{mm}$

Fig. 7 Schematic diagram of concrete specimen

Table 1 Mixture proportions of concrete.

\begin{tabular}{|c|c|c|c|c|c|c|c|c|c|}
\hline \multirow[b]{2}{*}{$\begin{array}{l}\mathrm{G}_{\max } \\
\mathrm{mm}\end{array}$} & \multirow[b]{2}{*}{$\begin{array}{l}\text { Slump } \\
\mathrm{cm}\end{array}$} & \multirow[b]{2}{*}{$\begin{array}{l}\text { Air } \\
\%\end{array}$} & \multirow[b]{2}{*}{$\begin{array}{c}\text { W/C } \\
\%\end{array}$} & \multirow[b]{2}{*}{$\begin{array}{l}\text { s/a } \\
\%\end{array}$} & \multicolumn{5}{|c|}{ Unit weight $\left(\mathrm{kg} / \mathrm{m}^{3}\right)$} \\
\hline & & & & & Water & Cement & $\begin{array}{c}\text { Fine } \\
\text { agqregate }\end{array}$ & $\begin{array}{c}\text { Coarse } \\
\text { agqreqate }\end{array}$ & Admixture \\
\hline 20 & 10 & 4.5 & 60 & 46.1 & 162 & 270 & 858 & 1011 & 0.68 \\
\hline \multicolumn{10}{|c|}{$\begin{array}{l}\text { Cement : ordinary Portland cement, density }=3.15 \mathrm{~g} / \mathrm{cm}^{3} \\
\text { Fine aggregate : natural sand, density }=2.63 \mathrm{~g} / \mathrm{cm}^{3}, \text { water absorption }=1.79 \% \\
\text { Coarse aggregate : crushed stone, density }=2.66 \mathrm{~g} / \mathrm{cm}^{3} \text {, water absorption }=0.70 \% \\
\text { Admixture : air-entraining and water-reducing admixture }\end{array}$} \\
\hline
\end{tabular}


amount of the corroded rebar, the distribution of the chloride ion concentration, and the carbonation depth.

\subsubsection{Inspection of corrosion cracks}

Visual inspection of corrosion cracks on the concrete surface was carried out once every one to three months for indoor exposure specimens, and once every six months for outdoor specimens. The measured items were crack width and crack length.

\subsubsection{Measurement of half-cell potentials}

Half-cell potentials were measured as shown in Fig. 9, which illustrates the electronic connection of the copper wires and potential meter, and the measuring method of half-cell potentials at $25 \mathrm{~mm}$ intervals using a $\mathrm{Pb}$ reference electrode on the concrete surface. The period of measurements for indoor specimens was the last day of the wetting cycle because the concrete surface was adequately wet. The half-cell potentials of outdoor specimens were measured on the concrete surface saturated with drinking water. The measured positions of half-cell potentials were spaced at $25 \mathrm{~mm}$ intervals on the concrete surface just over the rebar with $20 \mathrm{~mm}$ cover thickness.

\subsubsection{Measurement of corrosive product amount}

The corrosive product on the surface of the einforceing bar was removed in a $10 \%$ ammonium citrate solution at $60^{\circ} \mathrm{C}$ for 7.5 hours using the method recommended by the Japan Concrete Institute. Measurement of the configuration of the rebar cross-section is shown in Fig. 10. Figure 11 and Fig. 12 show the device. The configuration of the rebar, which was rotated on the device, was measured at thirty-six points, and intensively corroded areas were measured with a deformation gauge. The cross-section area of the rebar measured by this method was defined as a residual cross-section area and converted into corrosive product amount per unit area using the density of Fe and unit length.

\subsubsection{Measurement of chloride ion concentra- tion}

Two areas were selected for measuring the chloride ion concentration. One was the non-crack- surface and the other was the crack surface. The reason why two areas

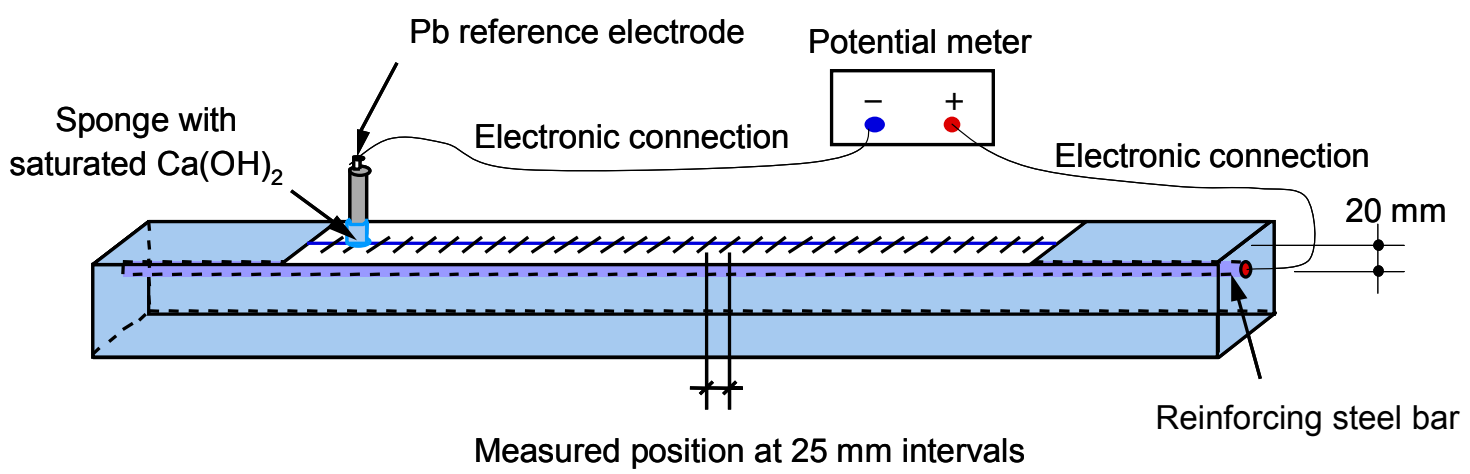

Fig. 9 Measurement of half-cell potentials.

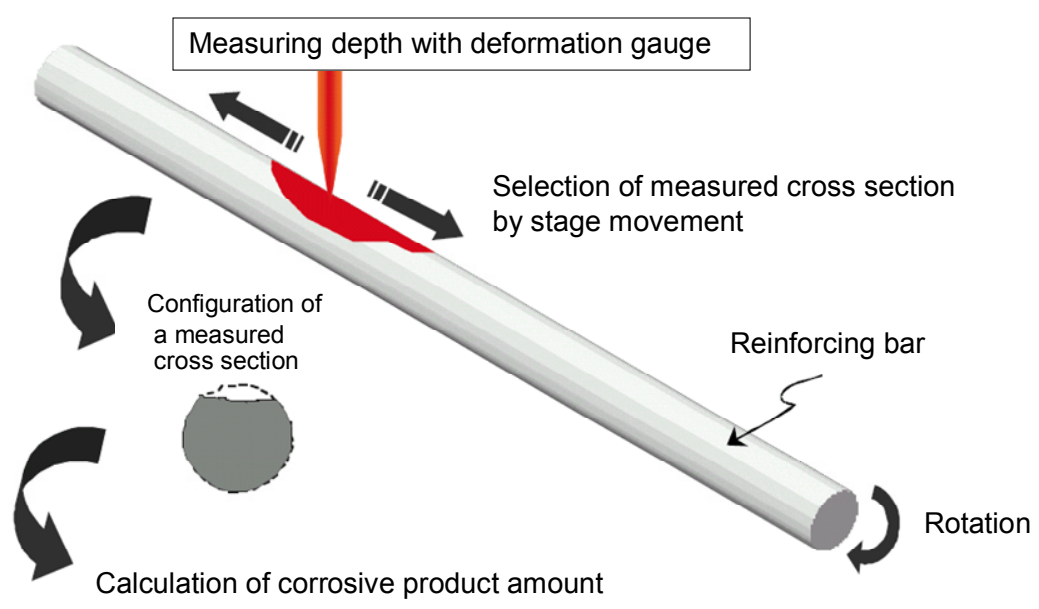

Pretreatment : $10 \%$ ammonium citrate, $60^{\circ} \mathrm{C}, 7.5$ hours

Fig. 10 Measuring configuration of rebar cross-section. 


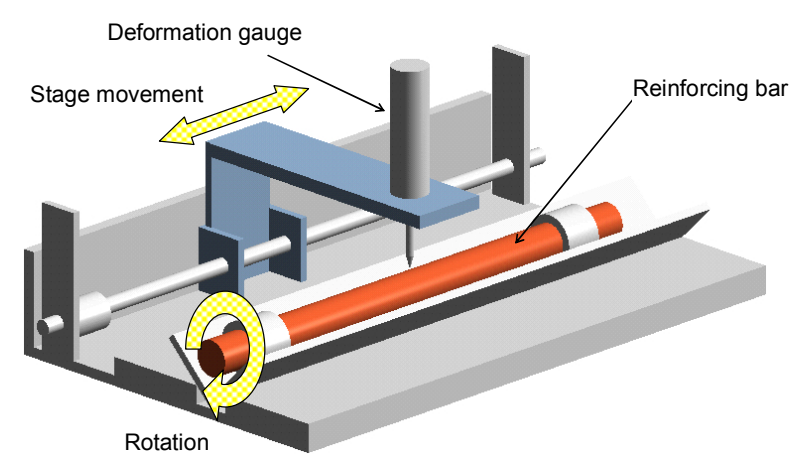

Fig. 11 Device for measuring configuration of rebar cross-section.

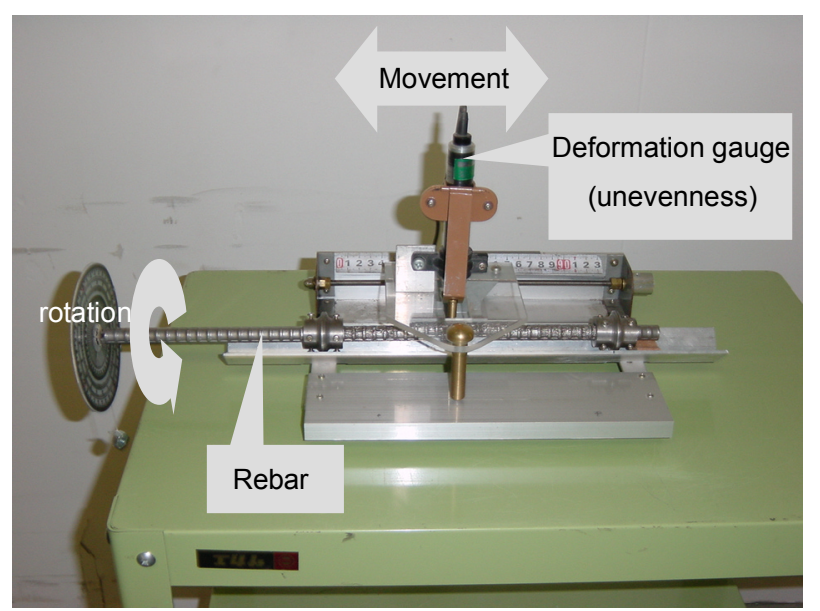

Fig. 12 Device of configuration of rebar cross section.

were selected is that differences in concrete surface conditions were found to have a clear influence on the distribution of chloride ion concentration. The chloride ion concentration was measured in conformity to the Japanese Industrial Standard method for testing chloride ion content in hardened concrete (JIS A 1154). The carbonation depth was measured by using phenolphthalein spray.

\section{Formulation for proposed micro-cell Corrosion model}

\subsection{General}

Following a brief explanation of the process of micro-cell corrosion, the stages of which are schematized in Fig. 13, this section discusses the features and the formulation of the proposed micro-cell corrosion model.

The cathodic polarization curve is shown as a line that slants to the right and passes through the coordinate $\left(i_{c o}\right.$, $\mathrm{E}_{\mathrm{co}}$ ) that is the equilibrium potential for cathodic reaction in the Evans diagram. The slope of the cathodic polarization curve in this research is constant on the horizontal log scale axis, but the cathodic current density is not over the limiting current density $i_{\text {lim }}$, which depends on the oxygen supply. The cathodic polarization curve can be formulated with the coordinate of the equilibrium po-

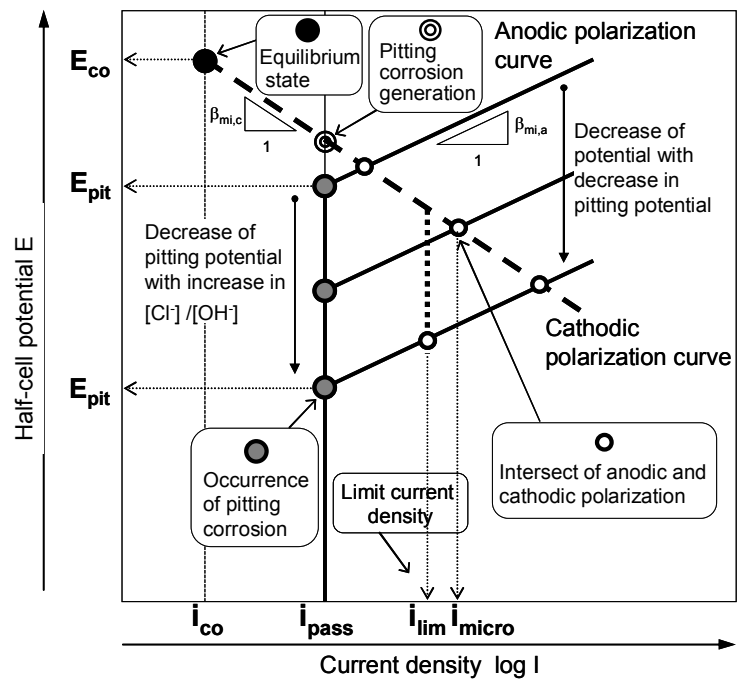

Fig. 13 Stages of micro-cell corrosion process.

tential and the slope of the cathodic polarization curve.

The anodic polarization curve is shown as two lines, one a vertical line that passes through the coordinate $\left(i_{\text {pass }}\right.$, 0 ), and the other a line that slopes toward the upper right in the Evans diagram. The anodic polarization curve can be formulated with the coordinate of the occurrence of pitting corrosion $\left(\mathrm{i}_{\text {pass }}, \mathrm{E}_{\mathrm{pit}}\right)$ and the slope of the anodic polarization curve. Pitting corrosion density $i_{\text {pass }}$ is the constant and pitting potential $\mathrm{E}_{\mathrm{pit}}$ is the function of $\left(\left[\mathrm{Cl}^{-}\right] /\left[\mathrm{OH}^{-}\right]\right)$in pore solution.

\subsection{Anodic polarization curve and cathodic po- larization curve 4.2.1 Anodic polarization curve}

As shown in Fig. 13, the current density and potential of the anodic polarization curve can be inferred (Bird et al. 1988, Kranc and Sagues 1997) by the given ( $i_{\text {pass }}, E_{\text {pit }}$ ) (unit: $\mathrm{A} / \mathrm{cm}^{2}$ and $\mathrm{V}$ ) and activation Tafel slope $\beta_{\mathrm{mi}, \mathrm{a}}$ (unit: $\mathrm{V})$. Indeed, based on this observed relationship, the formulation for the simplified anodic polarization curve is given as Eq. (5).

$$
\begin{gathered}
E_{\text {micro }}=0.06 \times\left(\log \left(i_{\text {micro }}\right)-\log \left(i_{\text {pass }}\right)\right)+E_{\text {pit }} \\
E_{\text {micro }} \geq E_{\text {pit }} \quad \text { (without existence of passive film) } \\
i_{\text {pass }}=5.8 \times 10^{-8} \\
E_{\text {micro }} \leq E_{\text {pit }} \quad \text { (with existence of passive film) } \\
i_{\text {pass }}=5.8 \times 10^{-8}
\end{gathered}
$$

where $\mathrm{E}_{\text {micro }}=$ Half-cell potential $(\mathrm{V}), \mathrm{E}_{\mathrm{pit}}=$ Pitting potential $(\mathrm{V}), \mathrm{i}_{\text {micro }}=$ Current density $\left(\mathrm{A} / \mathrm{cm}^{2}\right)$, and $\mathrm{i}_{\text {pass }}=$ Current density of passive state $\left(\mathrm{A} / \mathrm{cm}^{2}\right)$.

\subsubsection{Pitting potential}

The pitting potential is formulated as Eq. (6) (Bird et al. 1988). It is important to set $\left[\mathrm{OH}^{-}\right]$appropriately because 
$\mathrm{E}_{\mathrm{pit}}$ is changeable even if $\left[\mathrm{Cl}^{-}\right]$is set aptly from this equation.

$$
E_{p i t}=3.4-2.3 \times \log \left(\left[C /^{-}\right] /\left[O H^{-}\right]\right)
$$

where $\mathrm{E}_{\mathrm{pit}}=$ Pitting potential $(\mathrm{V}),\left[\mathrm{Cl}^{-}\right]=$Chloride ion concentration $(\mathrm{mol} / \mathrm{l})$, and $\left[\mathrm{OH}^{-}\right]=$Hydroxyl ion concentration $(\mathrm{mol} / \mathrm{l})$.

\subsubsection{Cathodic polarization curve}

The cathodic polarization curve is formulated as Eq. (7) (Japan Conc. Inst. 1996).

$$
\begin{aligned}
& E_{\text {micro }}=E_{c o}-0.24 \times\left(\log \left(i_{\text {micro }}\right)-\log \left(i_{c o}\right)\right) \\
& i_{c o}=6.25 \times 10^{-10}
\end{aligned}
$$

where $\mathrm{E}_{\text {micro }}=$ Half-cell potential $(\mathrm{V}), \mathrm{E}_{\mathrm{co}}=$ Equilibrium potential (V), and $\mathrm{i}_{\mathrm{co}}=$ Exchange current density $\left(\mathrm{A} / \mathrm{cm}^{2}\right)$.

\subsubsection{Equilibrium potential of cathodic reaction}

The equilibrium potential of the cathodic reaction is formulated as Eq. (8) (Bird et al. 1988).

$$
\begin{aligned}
& E_{c o}=0.914-0.0591 \times p H \\
& +0.015 \times \log \left(p O_{2}\right)
\end{aligned}
$$

where $\mathrm{E}_{\mathrm{co}}=$ Half-cell potential $(\mathrm{V}), \mathrm{pH}=\mathrm{pH}$ in pore solution, and $\mathrm{pO}_{2}=$ Partial pressure of oxygen (atom).

\subsubsection{Limiting current density}

The limiting current density is formulated as Eq. (9) (Jones, D. A., 1996) and Eq. (10) (Japan Conc. Inst. 1996).

$$
I_{\text {lim }}=\frac{D n F C_{B}}{\delta}
$$

where $\mathrm{I}_{\text {lim }}=$ Limiting current density $\left(\mathrm{A} / \mathrm{cm}^{2}\right), \mathrm{D}=$ Diffusion coefficient of oxygen $\left(1 \times 10^{-5} \mathrm{~cm}^{2} / \mathrm{s}\right), \mathrm{n}=$ valence $\left(4\right.$ for $\left.\mathrm{O}_{2}\right), \mathrm{F}=$ Faraday constant $(96500 \mathrm{c} / \mathrm{eq}), \mathrm{CB}=$ Concentration of dissolved oxygen $(\mathrm{mol} / \mathrm{l})$, and $\delta=$ Diffusion layer of oxygen on the surface of the rebar $(0.05$ $\mathrm{cm})$.

$$
I_{\text {lim }}=\frac{M}{2.591 \times 10^{-6}}
$$

where $\mathrm{I}_{\text {lim }}=$ Limiting current density $\left(\mathrm{A} / \mathrm{cm}^{2}\right)$, and $\mathrm{M}=$ Diffusion flux of oxygen on the surface of the rebar $\left(\mathrm{mol} / \mathrm{s} / \mathrm{cm}^{2}\right)$.

\section{Application of macro-cell model to experimental results and verification of the numerical simulation system}

\subsection{FEM partition of specimen and parameters for calculation}

Mass transfer and macro-cell corrosion were calculated by two-dimensional FEM based on a model divided into several elements consisting of $10 \mathrm{~mm}$ vertical intervals and $20 \mathrm{~mm}$ horizontal intervals, as shown in Fig. 14. The reason why two-dimensional analysis was carried out was that the movement of chloride ions is not always in one direction, especially at cracks, and the directions of chloride ion movement and the corrosion current differ. The parameters for calculation are listed in Table 2. The slopes of the macro-cell circuit in Fig. 4, which corresponds to the Tafel slopes of the micro-cell circuit, are shown in Eq. (11). The slopes are the function of the free
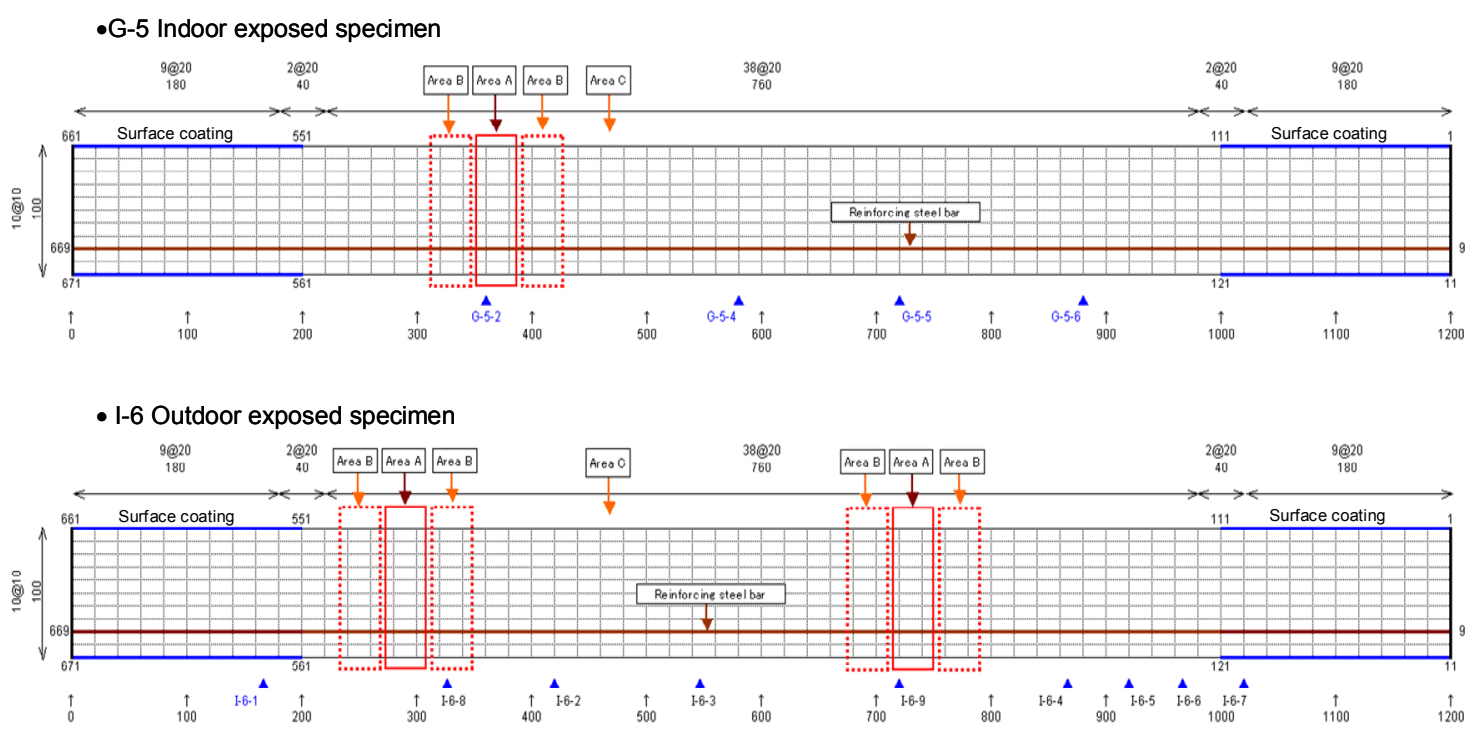

Diffusion coefficient of chloride ions was set up for Area A and Area B, respectively. Corrosion cracks were generated in both areas. There were no cracks in area $\mathrm{C}$.

Fig. 14 FEM Mesh partition of specimen for numerical analysis. 
chloride content, which was calculated by converting chloride ion concentration into mass content a unit cement weight.

$$
\begin{aligned}
& \beta_{\text {ma }, c}=0.037 \times \log \left(C_{\text {free }} / 0.593\right)-0.26 \\
& \beta_{\text {ma }, a}=-0.012 \times \log \left(C_{\text {free }} / 0.593\right)+0.19
\end{aligned}
$$

where $\beta_{\mathrm{ma}, \mathrm{a}}=$ Slope of anodic polarization curve, $\beta_{\mathrm{ma}, \mathrm{c}}=$ Slope of cathodic polarization curve, and $\mathrm{C}_{\text {free }}=$ Free chloride content $\left(\mathrm{kg} / \mathrm{m}^{3}\right)$

Table 2 Parameters for numerical analysis.

\begin{tabular}{|l|c|c|}
\hline \multicolumn{1}{|c|}{ Items } & Unit & Constant \\
\hline $\begin{array}{l}\text { Apparent concrete resistivity } \\
\text { (wet) }\end{array}$ & $\Omega \mathrm{cm}$ & 1800 \\
\hline $\begin{array}{l}\text { Apparent concrete resistivity } \\
\text { (dry) }\end{array}$ & $\Omega \mathrm{cm}$ & 5000 \\
\hline Atomic weight of Fe & - & 55.84 \\
\hline Density of Fe & $\mathrm{mg} / \mathrm{cm}^{3}$ & 7870 \\
\hline Faraday constant & $\mathrm{C} / \mathrm{mol}^{\mathrm{eq}}$ & 96500 \\
\hline Diameter of rebar & $\mathrm{cm}$ & 1.27 \\
\hline $\begin{array}{l}\text { pH in pore solution } \\
\text { Exposure period (indoor) } \\
\text { G-5 }\end{array}$ & days & 1575 \\
\hline $\begin{array}{l}\text { Exposure period (outdoor) } \\
\text { I-6 days }\end{array}$ & 1305 \\
\hline
\end{tabular}

\subsection{Chloride ions movement}

\subsubsection{Controlled cyclic wet and dry in indoor experiment G-5}

The chloride ion concentration in pore solution at the position of the rebar was calculated by the method, which was constituted with moisture movement influencing on cyclic wetting and drying and with fixing to Friedel's salt and adsorption. The measured data and numerical simulation results for the distributions of chloride ion concentrations at the period of 1575 days of exposure are shown in Fig. 15. The diffusion coefficient in crack areas was larger than that in non-crack areas, but the anisotropic diffusion coefficient was not considered in the analysis.

\subsubsection{Natural cyclic wet and dry in outdoor ex- periment I-6}

The measured data and numerical simulation results for distributions of chloride ion concentration at the period of 1305 days of exposure are shown in Fig. 16. In this case, the boundary chloride ion concentration in crack areas was set larger than that in non-crack areas. The diffusion coefficient of chloride ions was set up for Area A and Area B, respectively. Corrosion cracks were generated in both areas. There were no cracks in area C.

\subsection{Threshold value of chloride ion concentra- tion}

The time-dependent variation of half-cell potentials along the rebar in concrete is shown in Fig. 17. A remarkable decrease in half-cell potential starts after corrosion generation ( ) and then the potential stabilizes, but there are large differences between measured points. In this paper, the period when corrosion starts is defined as the period when a remarkable decrease in half-cell potential starts. At that point, the chloride ion concen-

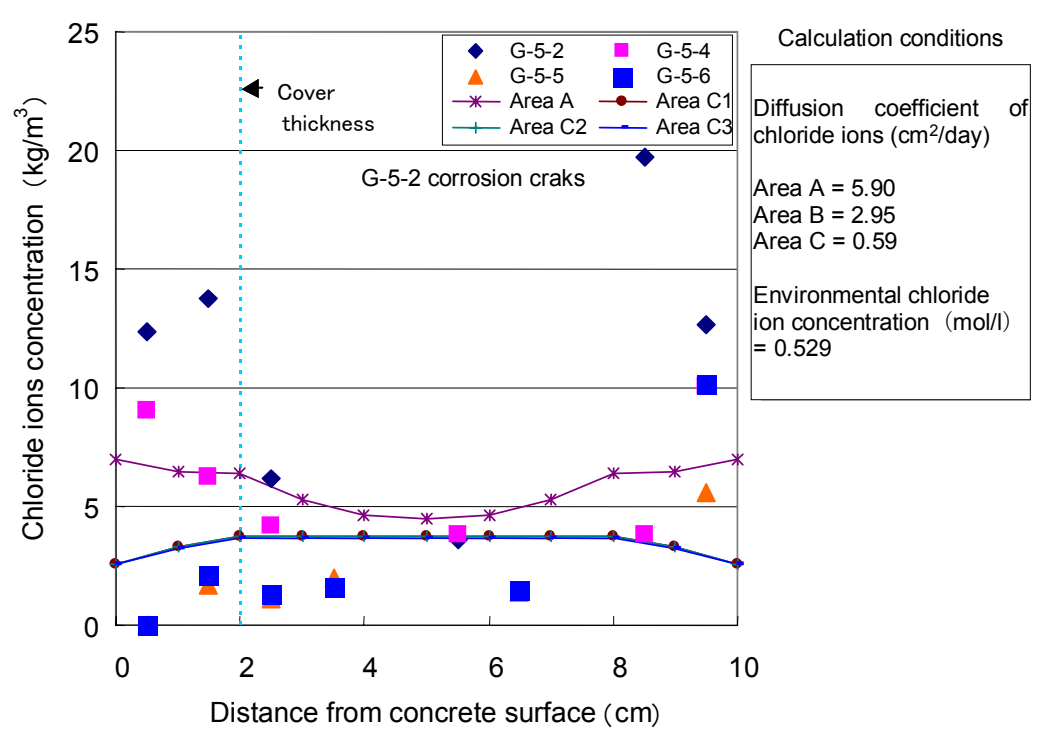

Fig. 15 Distribution of chloride ion concentration (Indoor-exposed specimen G-5). 
tration was measured at the position of the rebar and $\left[\mathrm{Cl}^{-}\right] /\left[\mathrm{OH}^{-}\right]$was calculated.

$E_{\text {pit }}$ from Eq.(6) with calculated $\left[\mathrm{Cl}^{-}\right] /\left[\mathrm{OH}^{-}\right]$corresponds to pitting potential $\mathrm{E}_{\text {pit }}$ and to the intersect of the cathodic polarization curve with adequate oxygen and the vertical line representing passive current density in Fig. 13. The value $\left[\mathrm{Cl}^{-}\right] /\left[\mathrm{OH}^{-}\right](=41.2)$ calculated in this research is indefinite because the chloride ion concentration was not measured at the beginning of corrosion generation and the $\mathrm{pH}$ value was assumed to be the one in Table 2. The value is higher than the range from 0.4 to 10.0 that is considered to be normal (Glass and Buenfeld 1997). Therefore it is clear that the value of $\left[\mathrm{Cl}^{-}\right] /\left[\mathrm{OH}^{-}\right]$ depends to a great extent on the $\mathrm{pH}$ value and that it is important to set the value $\left[\mathrm{OH}^{-}\right]$. For example, the value of $\left[\mathrm{Cl}^{-}\right] /\left[\mathrm{OH}^{-}\right]$is 4.12 for the $\mathrm{pH}$ value of 13.2.
5.4 Time-dependent variation and comparison with environmental conditions of measured half-cell potential

5.4.1 Time-dependent variation of measured half-cell potential

Time-dependent variation of the measured half-cell potential of G-5 is shown in Fig. 17. The potential increases abruptly immediately after exposure, then is stable between $-350 \mathrm{mV}$ and $-200 \mathrm{mV}$, and decreases radically after 450 days. After 600 days the difference between the maximum and minimum value of half-cell potential is $200 \mathrm{mV}$. The reason why potentials are different is that the anodic polarization curve is different due to chloride ion concentration and the cathodic polarization curve is different due to oxygen concentration.

The time-dependent variation of the measured half-cell potential of I-6 is shown in Fig. 18. The potential does not decrease abruptly as G-5 but decreases

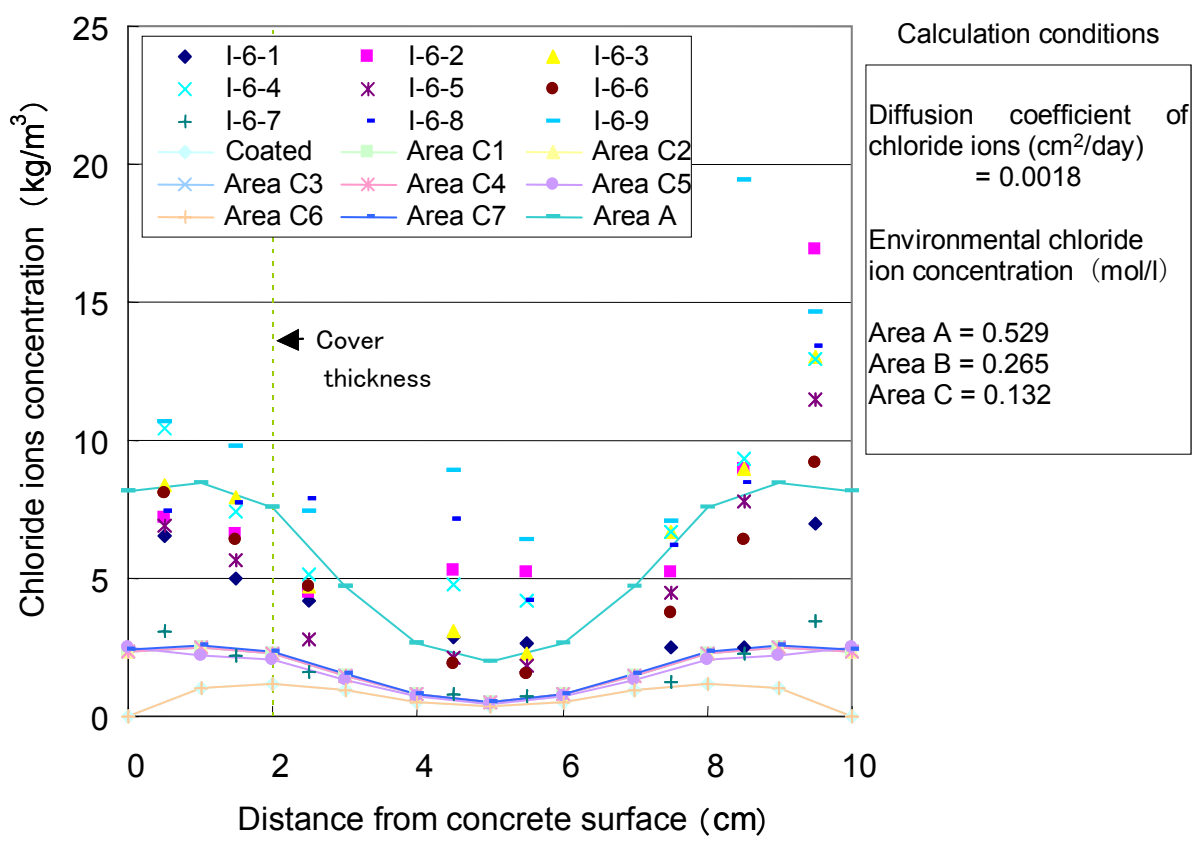

Fig. 16 Distribution of chloride ion concentration (Outdoor-exposed specimen I-6).

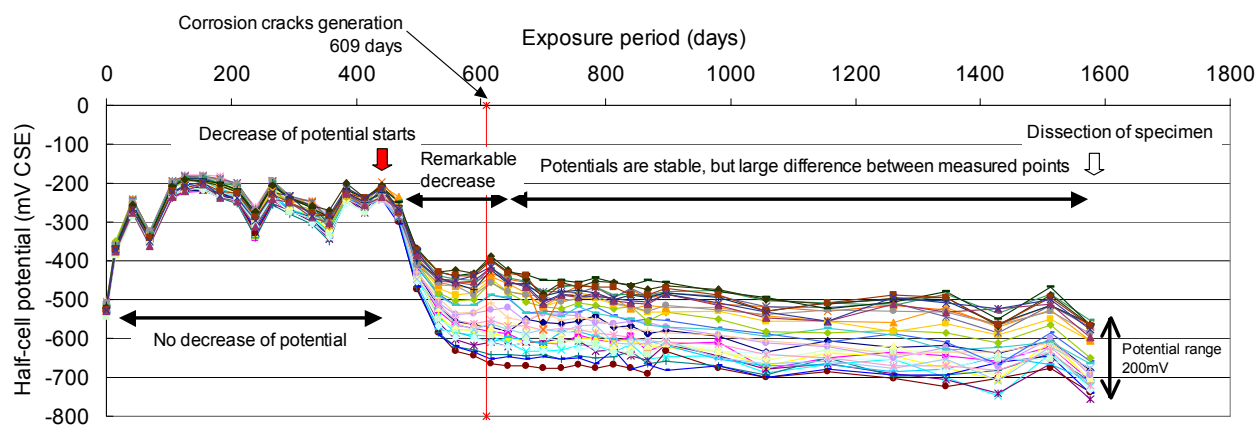

Fig. 17 Potential data of G-5, indoor exposure. 
slowly with the potential difference of $200 \mathrm{mV}$ after 200 days.

\subsubsection{Comparison the potential of indoor expo- sure with that of outdoor exposure}

The half-cell potential data of G-5 with the exposure period compressed as $1 / 2.2$ for the actual period and of I-6 with the actual exposure period are shown in Fig. 19.

\subsection{Verification of adjustment on measured half-cell potential and numerical simulation re- sults}

5.5.1 Indoor-exposed specimen (G-5)

The measured and simulated time-dependent data of the half-cell potential in both the cracks and non-crack areas are shown in Fig. 20, while the measured and simulated data distributions of the half-cell potential at 1575 days are shown in Fig. 21.

It is clear from Fig. 20 that the time-dependent half-cell potential of numerical simulation results and measured data in both crack and non-crack areas coincide with each other and the analysis is appropriate. However, the measured half-cell potential decreases abruptly and the numerical simulation results decrease gradually within the crack areas after 500 days of corrosion because the anodic polarization curve decreases as the chloride ion concentration increases in such range of this research in Fig. 13. The difference in half-cell po- tential between the measured data and numerical simulation results can be seen in Fig. 21, where the distribution of the measured half-cell potential is fluent along the rebar but distribution of numerical simulation results decreases abruptly in crack areas.

The contour of the half-cell potential and the direction of the current solved by Laplace's equation with the boundary condition of the potentials given by the macro-cell circuit model and no current at four concrete surfaces are shown in Fig. 22 (Yamamura and Ohtsu 1993). The formation of a macro-cell circuit is clear from this figure. The distribution of chloride ion concentration at the same time as Fig. 22 is shown in Fig. 23. It is clear that the chloride ion concentration is higher at the anodic position where current flows out of the concrete. The current density of the micro-cell circuit and macro-cell circuit are shown in Fig. 24. A positive sign in the current density of micro-cell circuit means a cathode, a negative sign means an anode, and the absolute value of the current density of micro-cell circuit is equal to that of the macro-cell. The position where the current density of the micro-cell circuit is the maximum coincides with that of the macro-cell circuit, but the current density values greatly differ from each other. The current density of the macro-cell circuit is seven times as high as that of the micro-cell circuit at the position where the current density is highest.

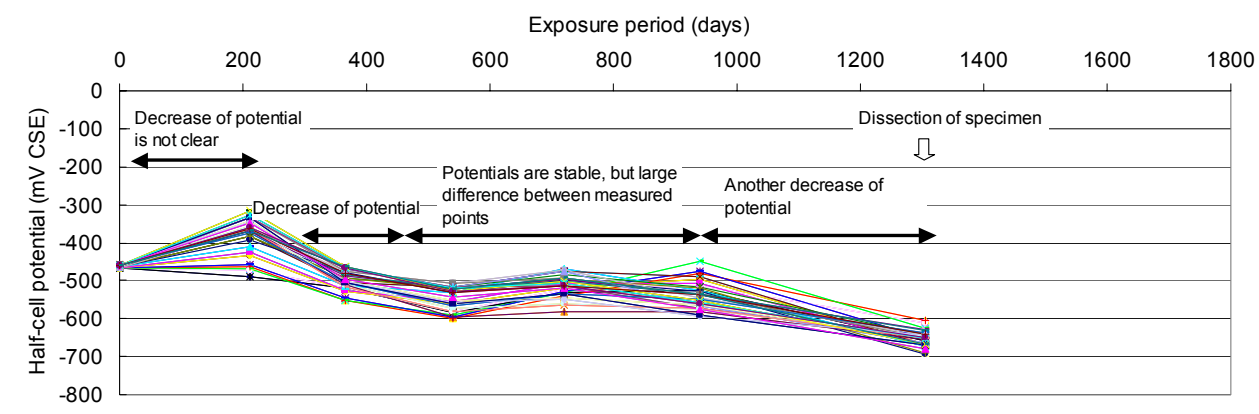

Fig. 18 Potential data of I-6, outdoor exposure.

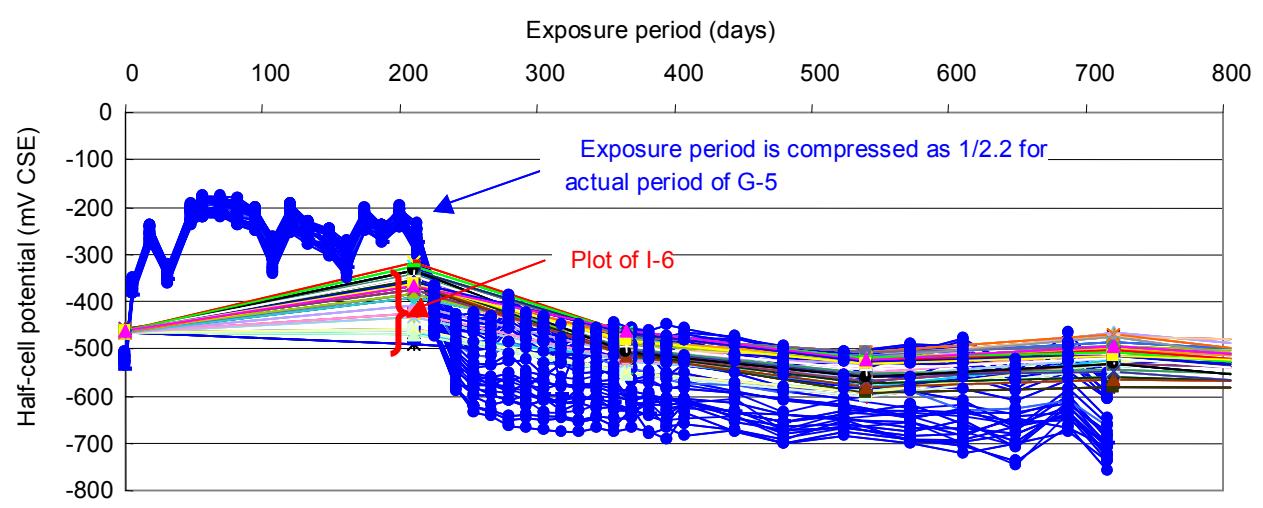

Fig. 19 Comparison of half-cell potential between two exposure environments. 
Exposure period (days)

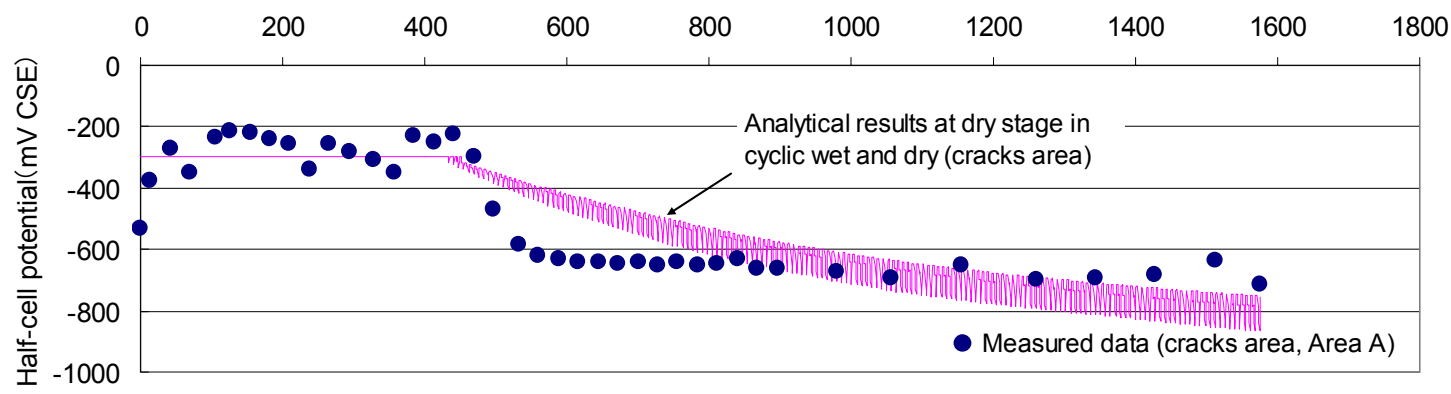

Exposure period (days)

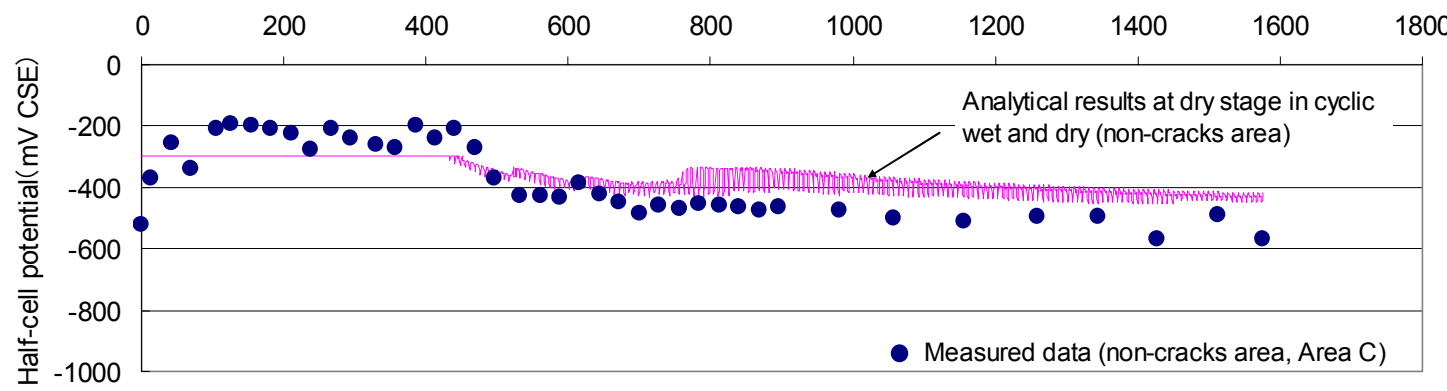

Fig. 20 Difference of half-cell potential between analytical results and measured data (G-5) (upper cracks part, lower non-cracks part).

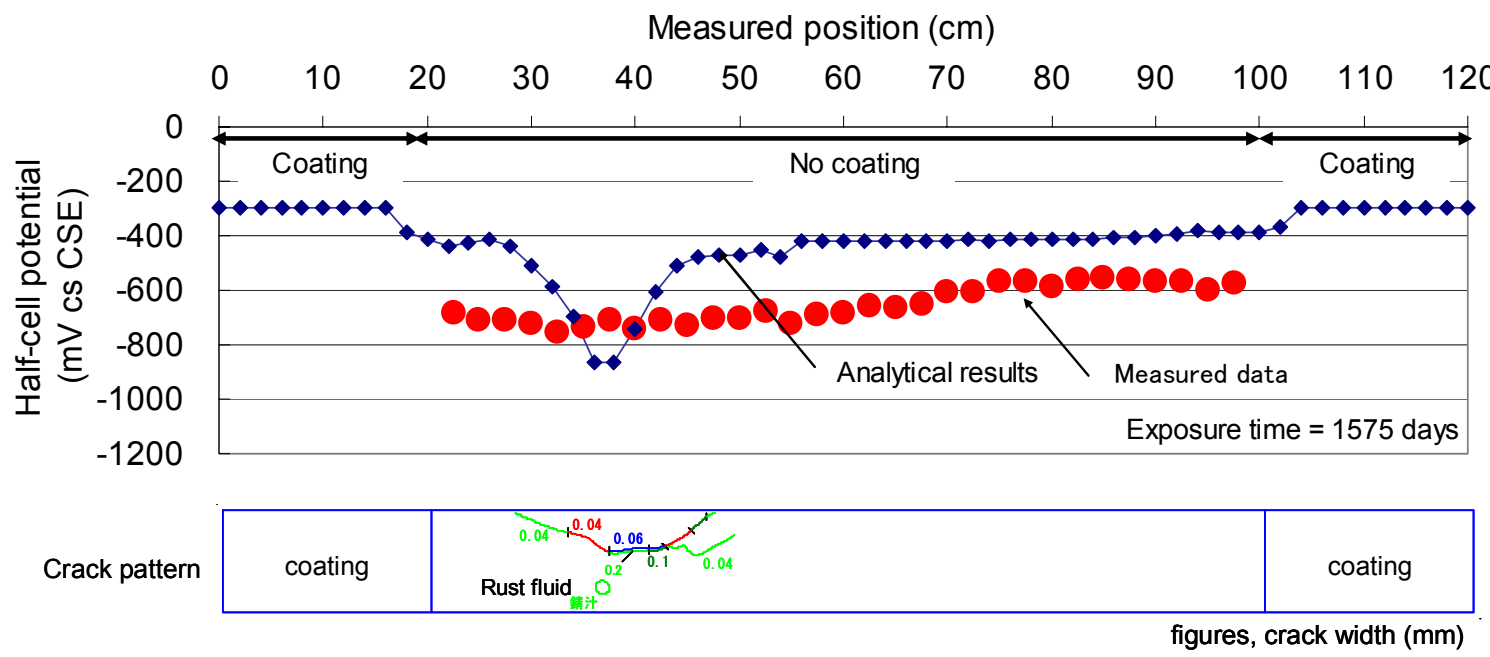

Fig. 21 Difference of half-cell potential distribution between analytical results and measured data (G-5).

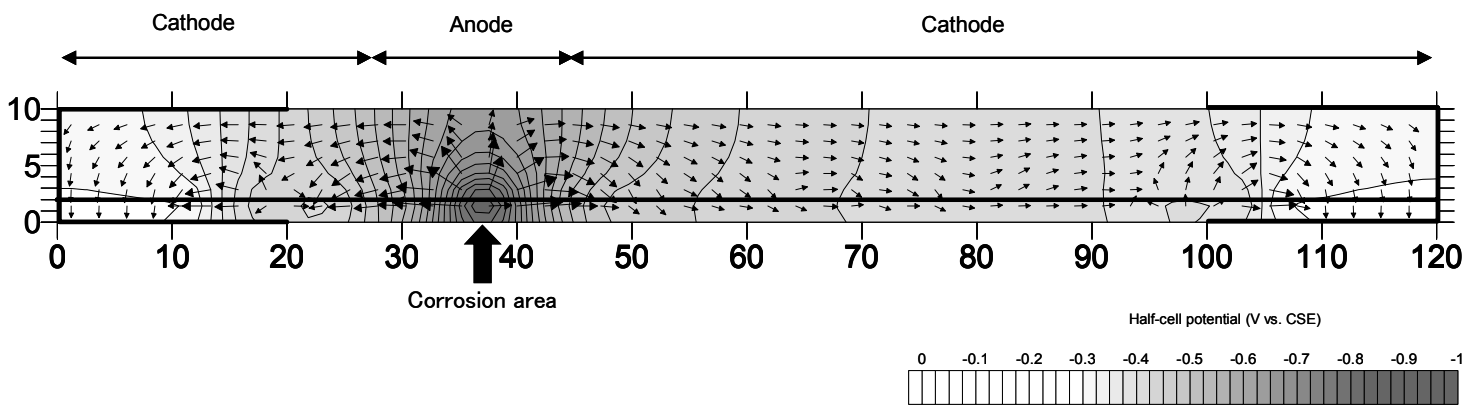

Fig. 22 Contour of half-cell potential and direction of current (G-5). 


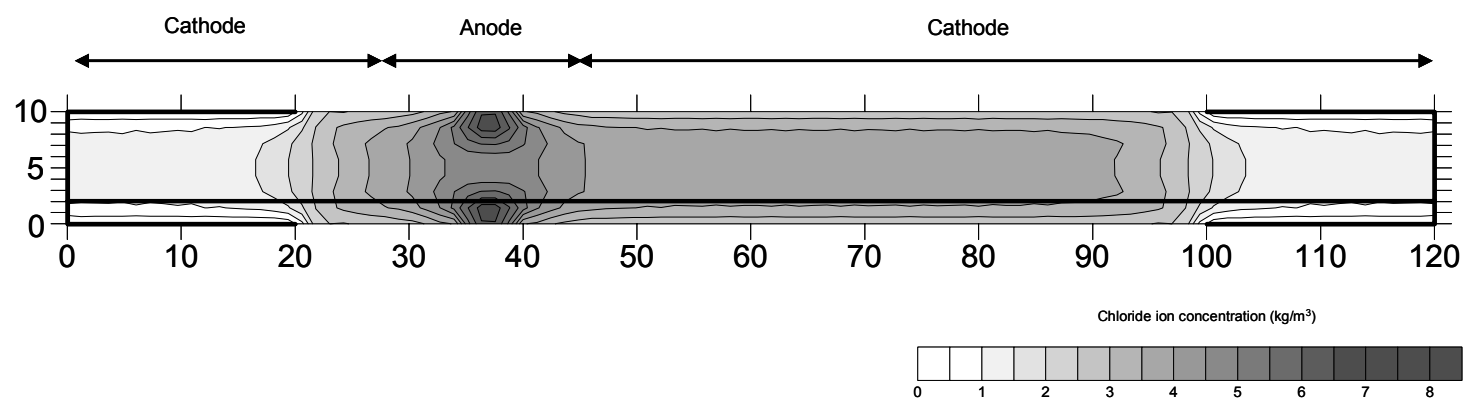

Fig. 23 Contour of chloride ions concentration (G-5).

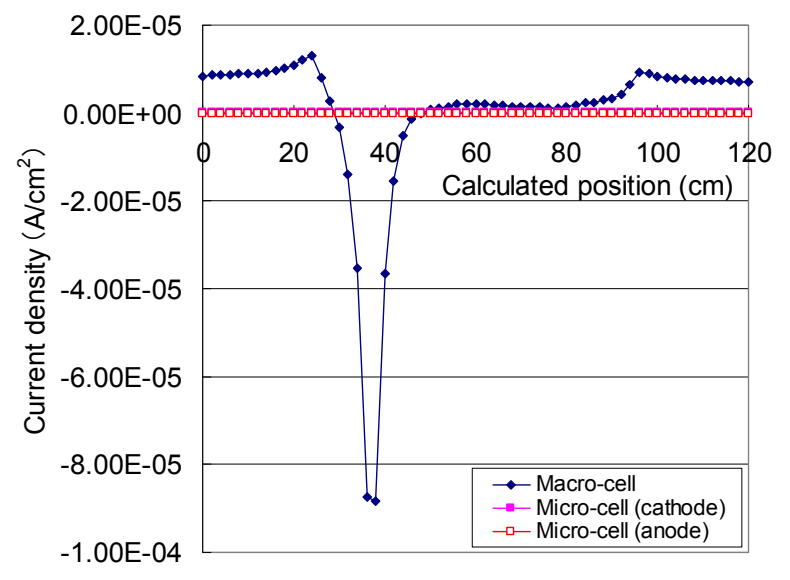

Fig. 24 Difference of current density between micro-cell and macro-cell circuit.

\subsubsection{Outdoor-exposed specimen (I-6)}

The measured and simulated time-dependent data of half-cell potential are shown in both crack areas and non-crack areas in Fig. 25, while the measured and simulated data distributions of half-cell potential at 1305 days are shown in Fig. 26. The wetting period is 3 days and the drying period is 8 days of cyclic wetting and drying in consideration of chloride movement. The half-cell potential of numerical simulation results barely coincides with that of measured data in the upper figure of Fig. 25. That is to say, the half-cell potential of measured data is almost not changeable but that of numerical simulation results has clear periods of generating corrosion and a clear tendency to change. On the other hand, the half-cell potential of numerical simulation results almost coincides with that of measured data because the range of the potential is small in the lower figure of Fig. 25. The initial period of corrosion is not clear for measured data. In Fig. 26, the distribution of the half-cell potential of measured data greatly differs from that of the numerical simulation results. That is to say, the measured half-cell potential in the cracks areas is almost the same as that in the non-crack areas, but the simulated half-cell potential in the crack areas is lower.

\subsection{Comparing measured corrosive product amount with simulated corrosive product amount}

\subsubsection{Indoor-exposed specimen (G-5)}

The measured and simulated distributions of corrosive product amount of G-5 are shown in both crack and non-crack areas in Fig. 27. The reason why not all plot points are shown in the figure is due to the fact that corrosion was not visually found on those measured points. By comparing the measured data with the numerical simulation results, the simulated corrosive product amount is higher than that of the measured data, which may be attributed to the small resistivity used for simulation.

\subsubsection{Outdoor-exposed specimen (I-6)}

The measured and simulated distributions of corrosive product amount of I-6 are shown in both the crack and non-crack areas in Fig. 28. There are two locations where corrosion cracks were found and the simulated corrosive product amount significantly increased. However, unlike the indoor-exposed specimens, the position showing maximum corrosion product amount differs between the measured data and numerical simulation results, which may be due to the fact that the chloride ion diffusion coefficient could not be appropriately set along the rebar.

\subsection{Future development issues of this numeri- cal simulation system}

The framework of the numerical simulation system of this study is based on the current density and potential within the micro-cell circuit due to chloride ion concentration and oxygen supply at the surface of the reinforcing steel bar as well as the formation of macro-cell circuits due to the potential differences of the polarization effect. Thus, the accuracy of the macro-cell current density and corrosive product amount depends on the calculation accuracy of the mass transport, half-cell potential and current density in the micro-cell circuit as well as the concrete resistance of the macro-cell circuit, etc. It is especially important for the inference of the half-cell potential within the micro-cell circuit that the anodic polarization curve, pitting potential and cathodic polarization curve be formed with greater accuracy as well as more reliable experimental verifications for the three sub-models. 
Exposure period (days)

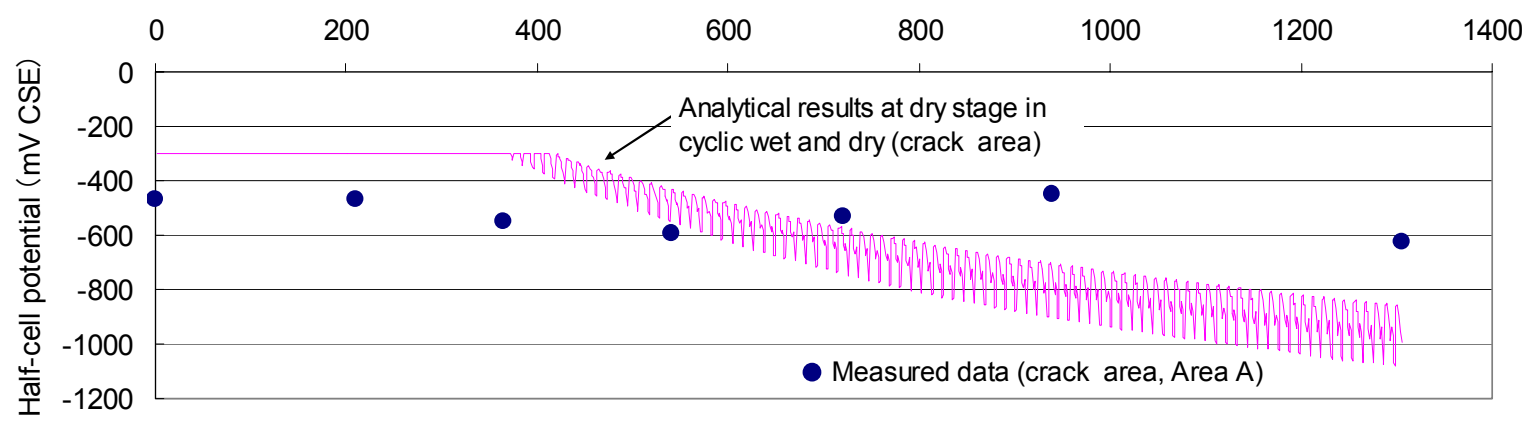

Exposure period (days)

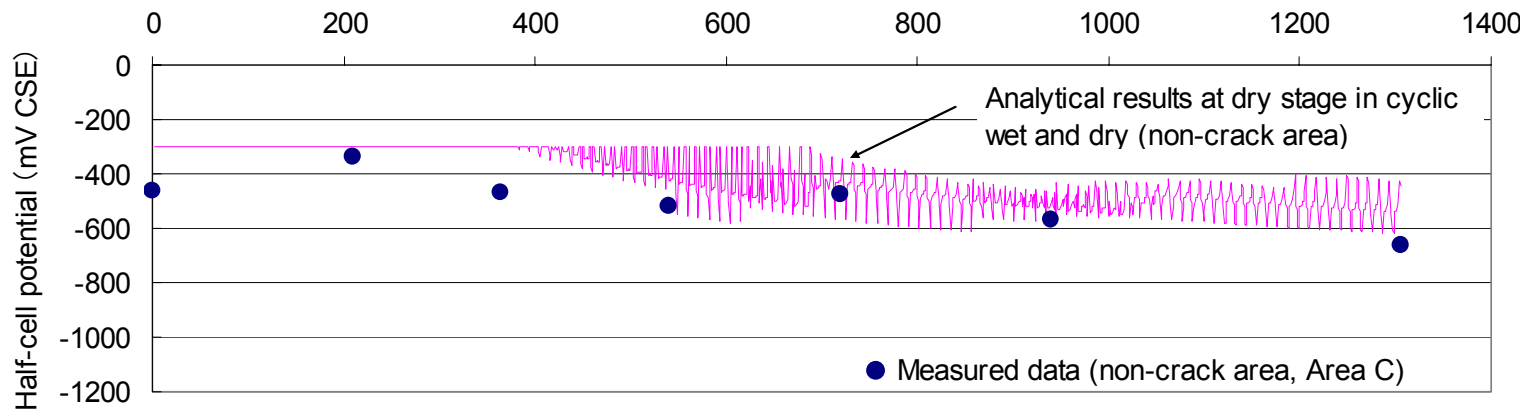

Fig. 25 Difference of half-cell potential between analytical results and measured data (I-6) (upper, crack area, lower, non-crack area).

Measured position (cm)
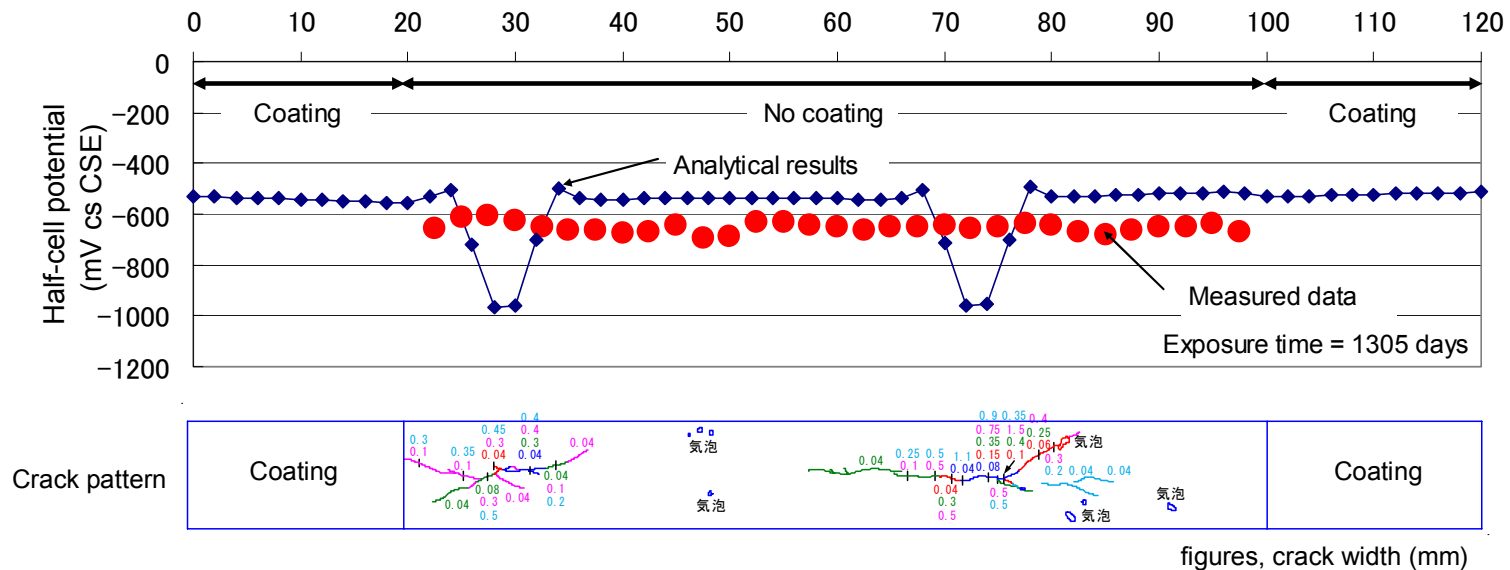

Fig. 26 Difference of half-cell potential distribution between analytical results and measured data (I-6).

Position of analysis and measurement $(\mathrm{cm})$

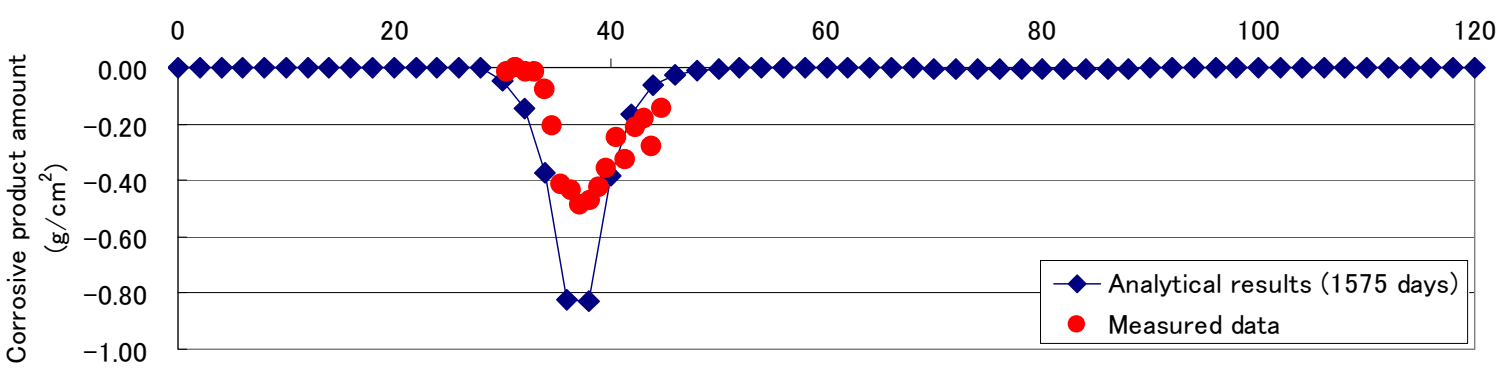

Fig. 27 Difference of corrosive product amount between analytical results and measured data (G-5). 


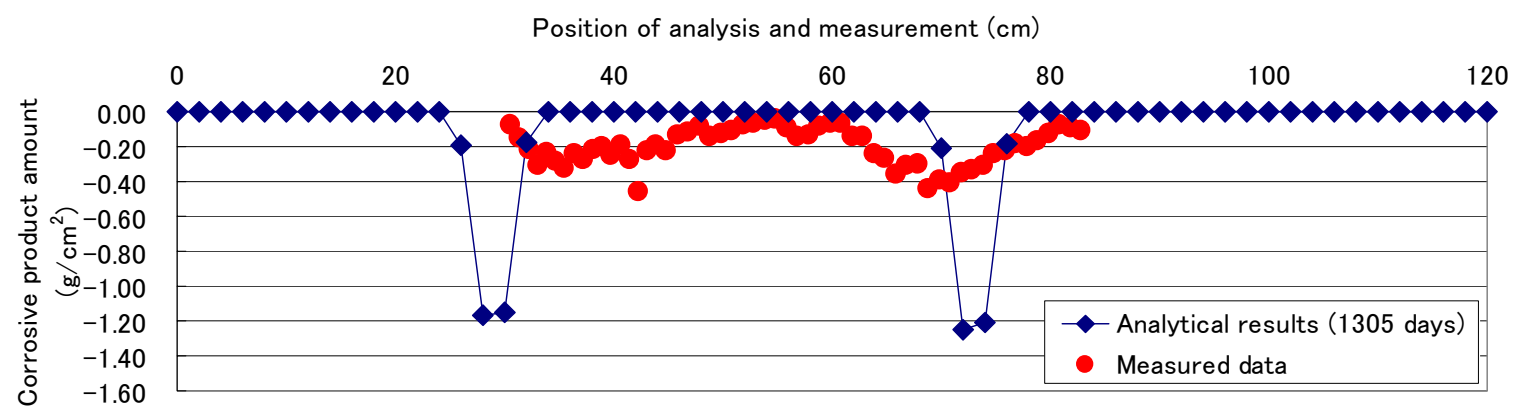

Fig. 28 Difference of corrosive product amount between analytical results and measured data (I-6).

\section{Simulation example for macro-cell circuit formation}

\subsection{Macro-cell circuit formation of patched re- pair}

When repairing concrete cross-sections with corroded reinforcing steel bars deteriorated by chloride ions, the half-cell potential of the unrepaired part is lower than that of the repaired part, because the potential in the patched area is noble with a lower chloride ion concentration. As a result, a corrosion circuit current occurs again owing to the difference in potential between the patched area and not-yet-patched area. Re-deterioration within the not-yet-repaired area around the patched area is known to occur in existing structures. A theoretical discussion of this phenomenon by Page (Page \& Sergi 2000) sought to explain the mechanism of macro-cell formation around the patched area by using an Evans diagram. According to their explanation, the half-cell potential of the not-yet-patched area becomes higher as the potential of the patched area increases, and corrosion progresses as the potential grows higher than the pitting potential. Strictly speaking, their explanation was imperfect because their observation implicitly expected macro-cell circuit formation. In other words, the polarization effect due to macro-cell circuit formation cannot be fully considered with an Evans diagram, which is valid for the micro-cell corrosion model. On the other hand, in this study, based on the concept of the macro-cell model shown in Fig. 1, there exists a macro-cell circuit due to the difference in half-cell potential resulting from the difference in chloride ion con- centration.

For clarification purposes, a numerical simulation, the layout of which is given in Fig. 29, was carried out. The central part of the virtual specimen was set as the patched area, repaired on the $1000^{\text {th }}$ day, and the simulated condition of diffusion of chloride ions and oxygen was the same as that of section 5.2.1 until the $1000^{\text {th }}$ day. The chloride ion concentration was higher in the not-yet-patched area than in the patched area due to total removal of chloride ions in the patched area during repair. The chloride ion diffusion coefficient in the patched area was set to 0.1 times that in the not-yet-patched area. The distribution of chloride ion concentration on the $1400^{\text {th }}$ day (i.e. 400 days after repair) is shown in Fig. 30, while the distribution of half-cell potential is given in Fig. 31, and the distribution of accumulated corrosive product amount is shown in Fig. 32. It is clear that the chloride ion concentration in the patched area is lower than in the not-yet-patched area in Fig. 30, and that the half-cell potential in the patched area is higher than in the not-yet-patched area in Fig. 31. In Fig. 32, the simulation result indicates that the position where the largest accumulated corrosive product amount can be found is not the boundary of the patched and not-yet-patched area but rather $8 \mathrm{~cm}$ from the boundary of the patched and not-yet-patched area. Conventionally, the most severe corrosion section is assumed to be located at the boundary of the patched and not-yet-patched area near the boundary of the patched and not-yet-patched area. Nevertheless, for the sake of taking the macro-cell corrosion circuit into account, the most severe corrosion location will be somewhat different from the boundary of the

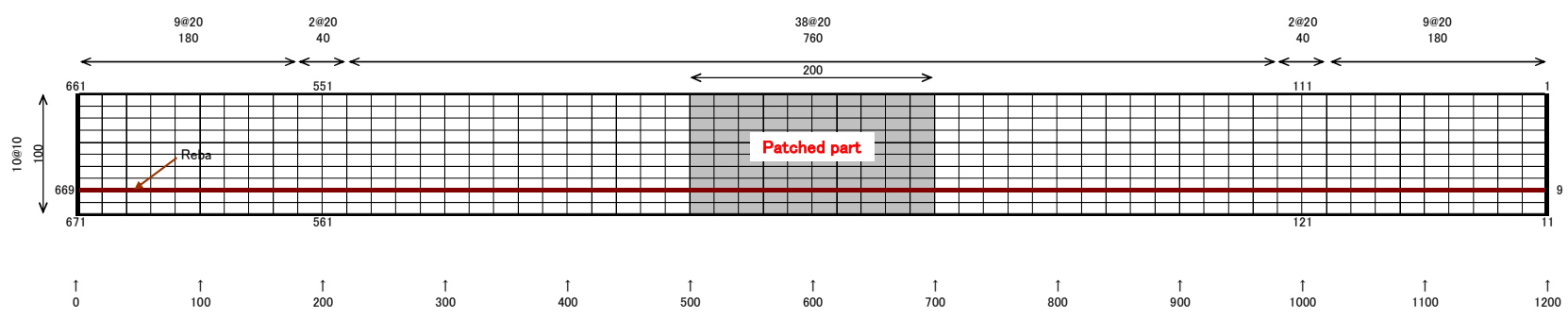

Fig. 29 Mesh size for virtual patched specimen. 


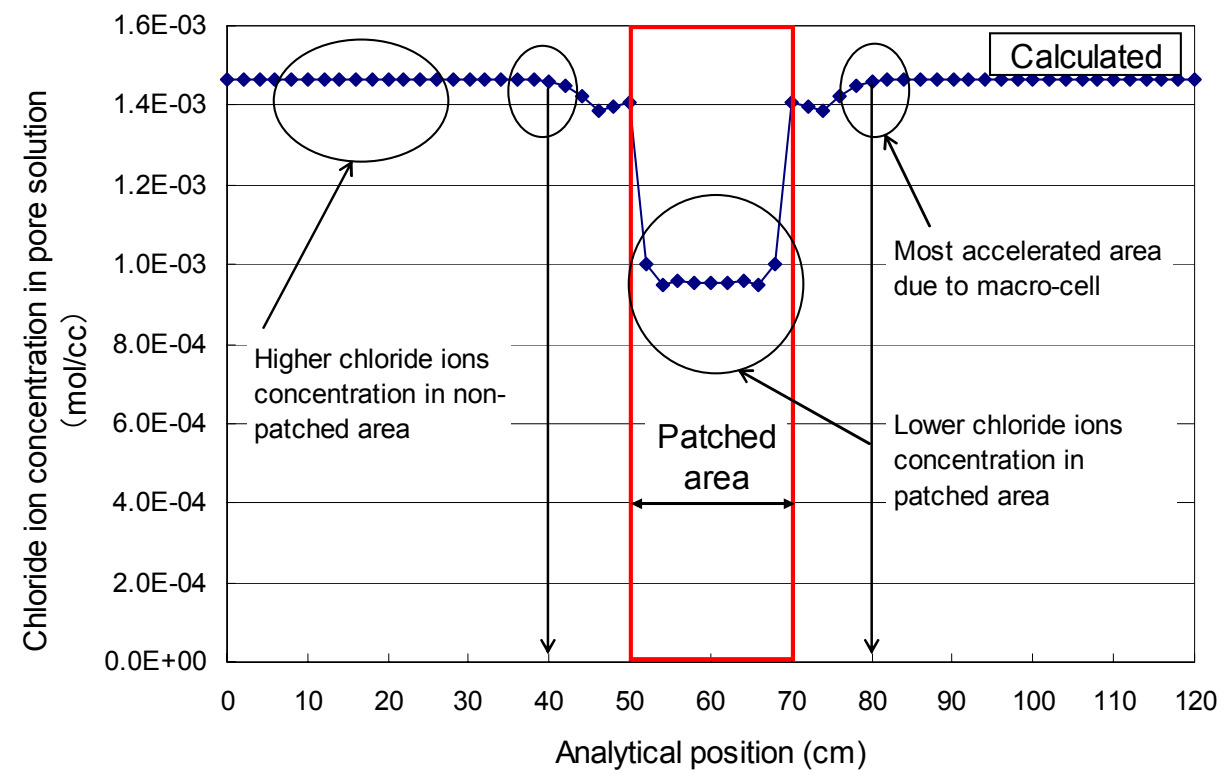

Fig. 30 Distribution of chloride ions concentration for virtual patched specimen.

Analytical position (cm)

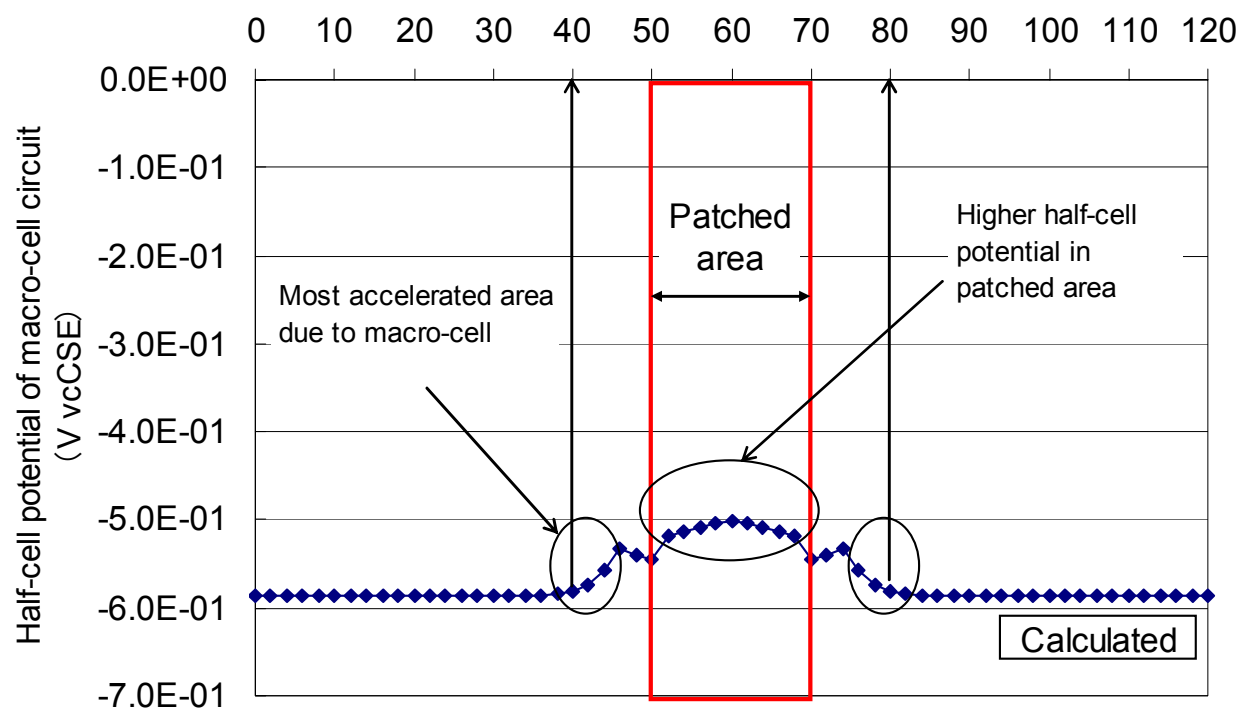

Fig. 31 Distribution of half-cell potential for virtual patched specimen.

patched and not-yet-patched area because the phenomenon differs from the corrosion-accelerating effect.

\subsection{Macro-cell circuit formation between double rebars}

When double rebars (inner rebar and outer rebar, with different concrete cover depth) are embedded in concrete, the half-cell potential of the outer rebar is lower than that of the inner rebar, on the condition that chloride ions penetrate into the concrete from the surface as the chloride ion concentration at the outer rebar is higher than that at the inner rebar. If the two rebars are connected electrically, corrosion current will naturally occur owing to the formation of a macro-cell circuit between the inner and the outer rebar. The literature contains investigations of macro-cell circuits occurring not only at a single rebar but also between electrically connected double rebars (Kobayashi et al. 1999). In our numerical simulation, the mesh partition of the virtual specimen is given in Fig. 33. The cover thickness, $1 \mathrm{~cm}$ and $2 \mathrm{~cm}$, is regarded as the control parameter. The diffusion condition of chloride ions and oxygen is the same as described in section 5.2.1, and the simulation period is 1700 days. The distribution of chloride ion concentration is shown in Fig. $\mathbf{3 4}$ on the 


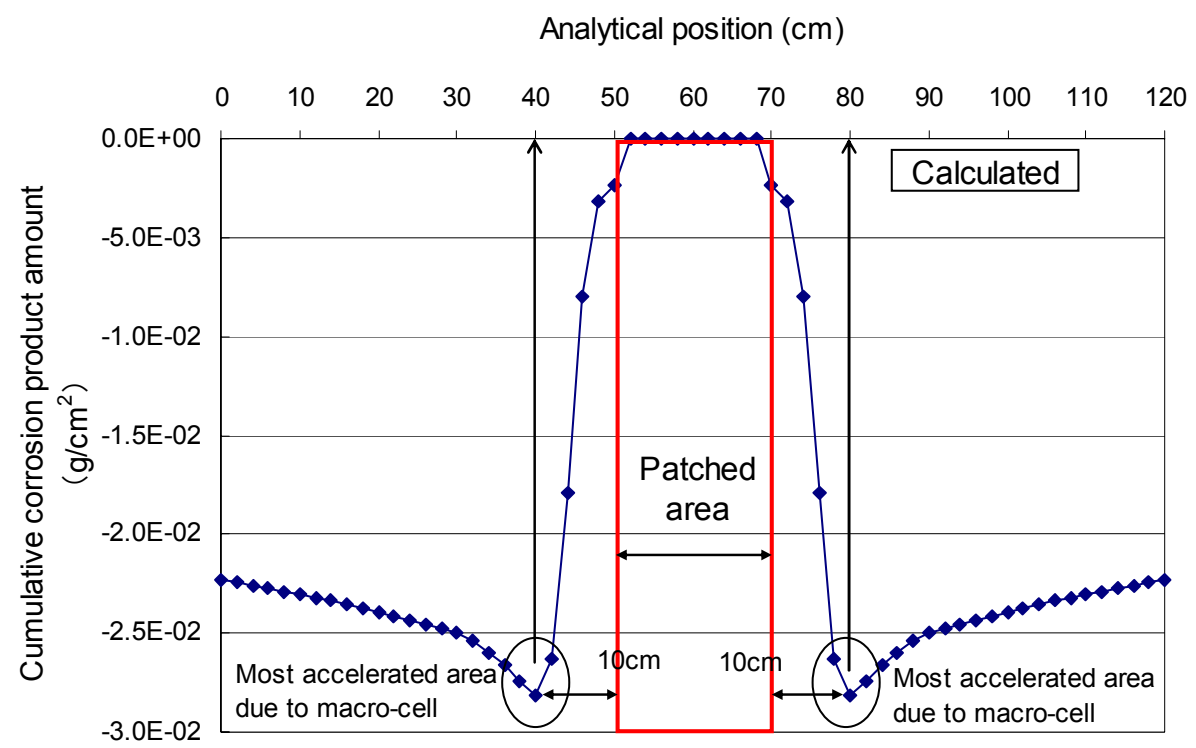

Fig. 32 Distribution of cumulative corrosive product for virtual patched specimen.

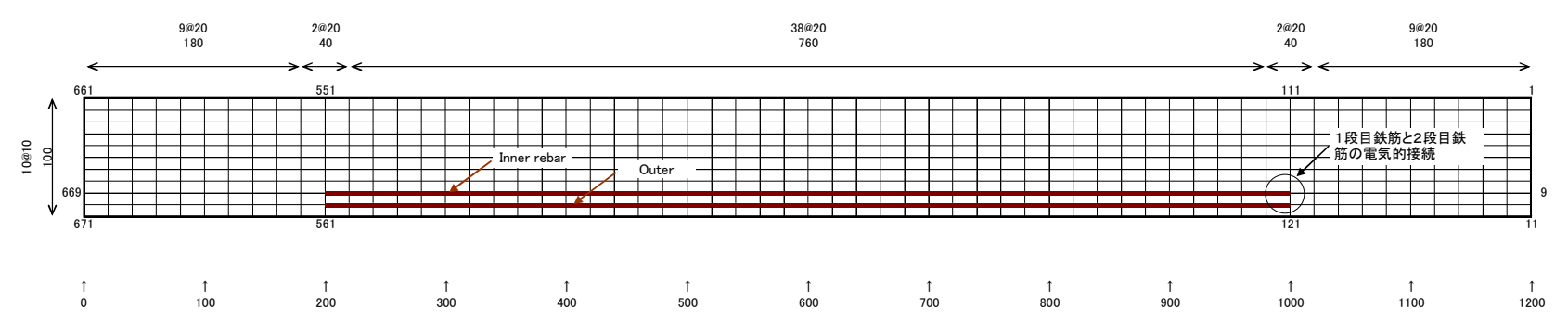

Fig. 33 Mesh size for virtual double-rebar specimen.

$1700^{\text {th }}$ day, the distribution of half-cell potential in Fig. 35 and Fig. 36, and the distribution of accumulated corrosive product amount in Fig. 37.

As shown in Fig. 34, the chloride ion concentrations of the inner rebar and the outer rebar both remain constant. Thus, the half-cell potential of the micro-cell circuit also remains constant on either the outer rebar or inner rebar, as can be seen in Fig. 35. However, if the two rebars are connected electrically and current is generated between them, the state of polarization varies and the half-cell potential due to the formation of a macro-cell circuit is different from that of the micro-cell circuit shown in Fig. 35 and Fig. 36. Figure 37 shows the accumulated corrosive product amount of the outer rebar on the $1700^{\text {th }}$ day. Within the central part of the outer bar, the half-cell potential is relatively low and the corrosive product amount is much greater due to the occurrence of macro-cell corrosion. This may be due to the fact that the macro-cell circuit length between the target element within the central part of outer rebar and the couple element within the inner rebar is shorter than the macro-cell circuit length between the target element within the edge part of the outer rebar and the couple element within the inner rebar.

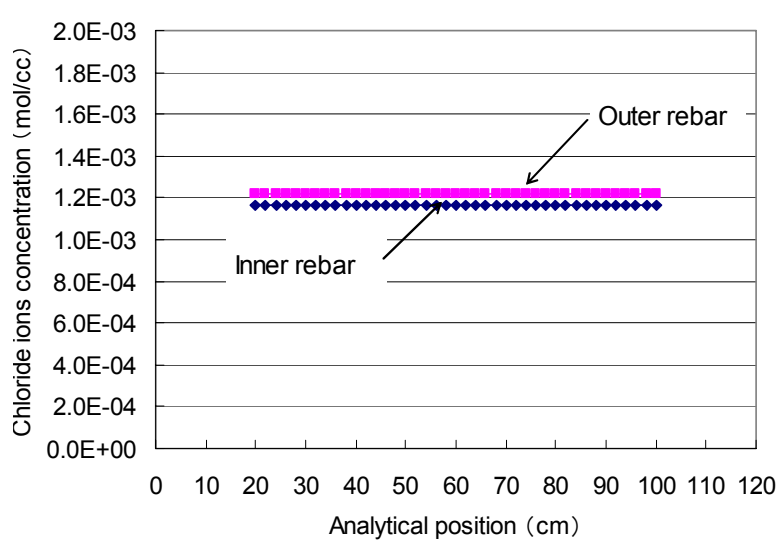

Fig. 34 Distribution of chloride ions concentration for virtual double-rebar specimen.

\section{Conclusions}

The following conclusions regarding the proposed numerical simulation system for corrosion of reinforcing steel bars owing to macro-cell circuit formation can be drawn based on the simulation results. 
Analytical position $(\mathrm{cm})$

$\begin{array}{lllllllllllll}0 & 10 & 20 & 30 & 40 & 50 & 60 & 70 & 80 & 90 & 100 & 110 & 120\end{array}$

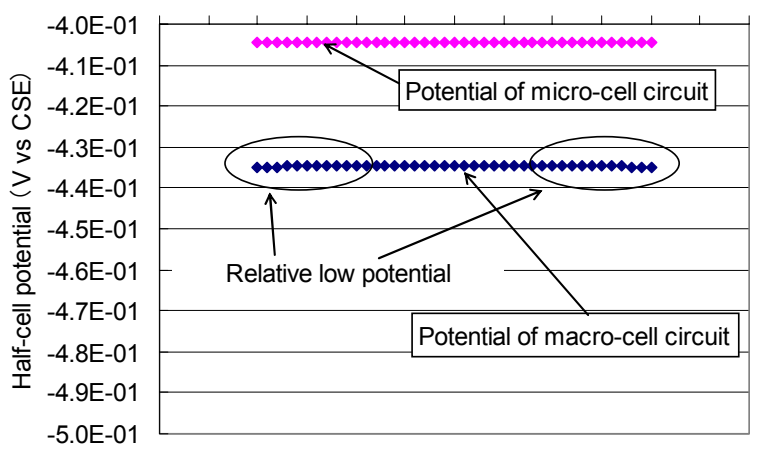

Fig. 35 Distribution of half-cell potential for virtual double-rebar specimen (inner rebar).

Analytical position (cm)

$\begin{array}{lllllllllllll}0 & 10 & 20 & 30 & 40 & 50 & 60 & 70 & 80 & 90 & 100 & 110 & 120\end{array}$

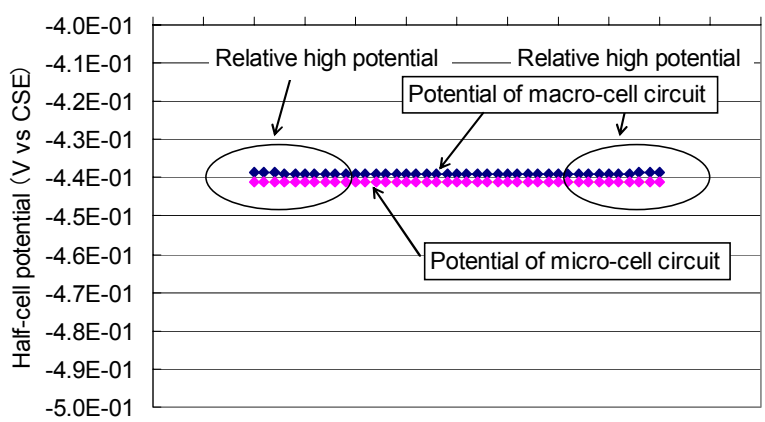

Fig. 36 Distribution of half-cell potential for virtual double-rebar specimen (outer rebar).

Analytical position $(\mathrm{cm})$

$\begin{array}{lllllllllllll}0 & 10 & 20 & 30 & 40 & 50 & 60 & 70 & 80 & 90 & 100 & 110 & 12\end{array}$

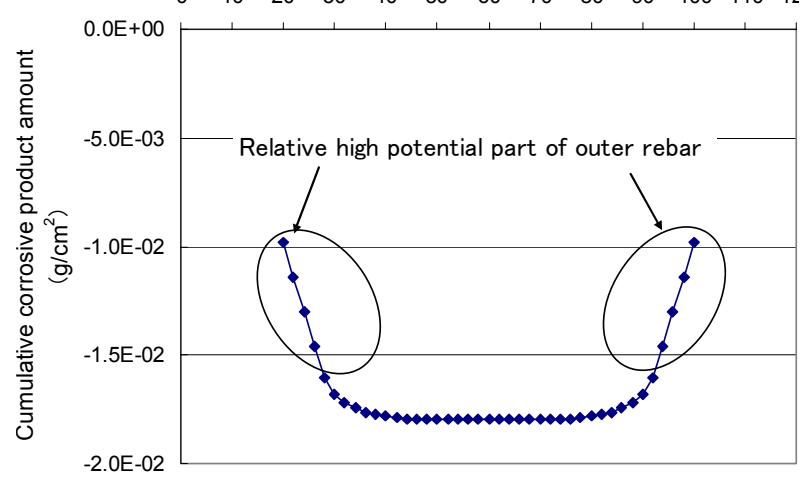

Fig. 37 Distribution of cumulative corrosive product amount for virtual double-rebar specimen.

(1) It is essential to properly build the micro-cell corrosion model to obtain a suitable anodic polarization curve and cathodic polarization curve and to calculate pitting corrosion. Parameters such as the chloride ion concentration and hydroxyl ions are used for the anodic polarization curve and pitting potential, $\mathrm{pH}$ is used as the parameter for the cathodic polarization curve, and the flux of oxygen at the surface of the rebar is used as the parameter for the limiting current density related to the cathodic reaction.

(2) To apply micro-cell potential to the formation of the macro-cell circuit, macro-cell model, for all the element couples along the rebar, it is proposed that the half-cell potential of the target element is the average of the half-cell potential of its couple elements and the current density of the target element is the accumulated current density of its couple elements.

(3) The applicability of the proposed micro-cell model, macro-cell model and numerical simulation system is experimentally verified by comparing the simulated half-cell potential and corrosive product amount with the experimental results of cyclic wet and dry exposure testing and splash zone exposure testing.

(4) The numerical simulation results of this study demonstrate that the corrosive product amount due to macro-cell corrosion is much larger than that due to micro-cell corrosion.

(5) The proposed models demonstrated numerically that the corrosion of the not-yet-patched area near the patched area is accelerated and that, in the case of a double rebar, the corrosion of the outer rebar is faster than that of the inner rebar.

(6) To enhance the estimation accuracy for the half-cell potential (an important index of corrosion) of micro-cell current circuits, it is indispensable to form the anodic polarization curve, pitting potential anodic polarization curve and cathodic polarization curve with higher reliability.

\section{References}

Bird, H. E. H., Pearson, B. R. and Brook, P. A. (1988). "The breakdown of passive films on iron." Corrosion Science, 28 (1), 81-86.

Elsener, B. (2003). "Electrochemical techniques for measuring metallic corrosion." RILEM TC 154-EMC "Recommendations, Half-Cell Potential Measurements - Potential Mapping on Reinforced Concrete Structures." Material and Structures, 36, 461-471.

Glass, G. K. and Buenfeld, N. R. (1997). "The presentation of the chloride threshold level for corrosion of steel in concrete." Corrosion Science, 39 (5), 1001-1013.

Hsu, K. L., Takeda, H. and Maruya, T. (1998). "Numerical simulation on migration of oxygen and carbon dioxide in concrete." Proc. of Japan Conc. Inst., 20 (1), 769-774.

Hsu, K. L., Takeda, H. and Maruya, T. (2000). "Numerical simulation on corrosion of steel in concrete structures under chloride attack." $J$. Materials, Concrete Structures and Pavements, Japan Soc. Civ. Eng., 48 (655), 143-157.

Japan Conc. Inst. (1996). "Technical report on repair 
methods of concrete structure (III)." (in Japanese)

Jones, D. A. (1996). "Principles and Prevention of Corrosion." 2nd ed. Upper Saddle River NJ: Prentice Hall.

Japan Soc. Civ. Eng. (2000). "The state of the art and trends in research on rebar corrosion, anticorrosion and repair technology (2nd report)." edited by Corrosion and Anticorrosion Subcommittee of Concrete Committee. (in Japanese)

Japan Soc. Civ. Eng. (2001). "Standard specifications for concrete structures." (in Japanese)

Kawahigashi, T., Kobayashi, K. and Miyagawa, T. (2003). "A study of macro-cell and micro-cell corrosion of steel in concrete." J. Materials, Concrete Structures and Pavements, Japan Soc. Civ. Eng., 59 (732), 1-16. (in Japanese)

Kobayashi, K., Watanabe, Y., Hatori, H. and Miyagawa, T. (1999). "Corrosion of steel bar in patched concrete member with self-compacting concrete damaged by chloride induced corrosion." J. Materials, Concrete Structures and Pavements, Japan Soc. Civ. Eng., 44 (627), 147-160 (in Japanese).

Koyama, R., Yajima, T., Uomoto, T. and Hoshino, F. (1996). "Prediction of steel corrosion portion and area by half-cell potential measurement." J. Materials, Concrete Structures and Pavements, Japan Soc. Civ. Eng., 33 (550), 13-22. (in Japanese)

Kranc, S. C. and Sagues, A. A. (1997). "Modeling the time-dependent response to external polarization of a corrosion macrocell on steel in concrete." $J$. Electrochem. Soc., 144 (8), 2643-2651.
Maruya, T., Tangtermsirikul, S. and Matsuoka, Y. (1998). "Modeling of chloride ion movement in the surface layer of hardened concrete." Concrete Library of Japan Soc. Civ. Eng., 32, 69-84. (in Japanese)

Nagataki, S., Otsuki, N., Moriwake, A., Kamada T. and Miyazato S. (1997). "Influence of permeability through joint on macrocell corrosion." J. Materials, Concrete Structures and Pavements, Japan Soc. Civ. Eng., 37 (578), 31-42. (in Japanese)

Otsuki, N., Miyazato, S., Suzuki, H. and Kimura, H. (1999). "Mechanism of chloride-induced corrosion on main rebars and stirrups near bending cracks." $J$. Materials, Concrete Structures and Pavements, Japan Soc. Civ. Eng., 44 (627), 161-177. (in Japanese)

Page, C. L. and Sergi, G. (2000). "Development in cathodic protection applied to reinforced concrete." $J$. Materials in Civil Engineering, American Soc. Civ. Eng., 12 (1),8-15.

Raupach, M. (1996). "Corrosion of steel in the area of cracks in concrete-Laboratory tests and calculations using a transmission-line model." Corrosion of Reinforcement in Concrete Construction, edited by C. L. Page, P. B. Bamforth and J. W. Figg, 13-23.

Takewaka, K. and Kobayashi, K. (1988). "Discussion on half-cell potential method for non-destructive test of rebar corrosion." Symposium on Durability Diagnosis of Concrete Structures, 79-84. (in Japanese)

Yamamura, K. and Ohtsu, M. (1993). "Investigation for rebar corrosion by half-cell potential CSM inverse analysis." Proc. of Japan Conc. Inst., 15 (1), 739-744. (in Japanese) 